\title{
Nanostructured recombinant cytokines: a highly stable alternative to short-lived prophylactics
}

Débora Torrealba ${ }^{1,2}$, David Parra ${ }^{2}$, Joaquin Seras-Franzoso ${ }^{1,3,4, \dagger}$, Eva Vallejos ${ }^{1}$, Daniel Yero $^{1,3}$, Isidre Gibert ${ }^{1,3}$, Antonio Villaverde ${ }^{1,3,4}$, Elena Garcia-Fruitós ${ }^{1,3,4}$ \$, \& and Nerea Roher $^{1,2, \$}$

\footnotetext{
${ }^{1}$ Institut de Biotecnologia i de Biomedicina (IBB), Universitat Autònoma de Barcelona, 08193 Cerdanyola del Vallès, Spain.

${ }^{2}$ Dep. de Biologia Cel-lular, Fisiologia Animal i Immunologia, Universitat Autònoma de Barcelona, 08193 Cerdanyola del Vallès, Spain

${ }^{3}$ Departament de Genètica i de Microbiologia, Universitat Autònoma de Barcelona, 08193 Cerdanyola del Vallès, Spain.

${ }^{4}$ CIBER de Bioingeniería, Biomateriales y Nanomedicina (CIBER-BBN), 08193 Cerdanyola del Vallès, Spain.

\$ co-corresponding authors: nerea.roher@uab.cat +345812805; elena.garcia@irta.cat +349346740 40

${ }^{\&}$ Present address: Department of Ruminant Production, IRTA, Institute of Agrifood Research and Technology. Torre Marimon, km 12,1 C-59, Caldes de Montbui, 08140, Barcelona, Spain.

† Present address: Cibbim-Nanomedicine, Hospital Vall d'Hebron, Institut de Recerca de la Vall d'Hebron (VHIR)

Passeig de la Vall d’Hebron, 119-129, 08035, Barcelona, Spain
}

\begin{abstract}
Cytokines have been widely used as adjuvants and therapeutic agents in treatments of human diseases. Despite their recognized potential as drugs, the medical use of cytokines has considerable drawbacks, mainly related to their low stability and short half-life. Such intrinsic limitations imply the administration of high doses, often prompting toxicity, undesirable side effects and greater production costs. Here, we describe a new category of mechanically stable nanostructured cytokines (TNF $\alpha$ and CCL4/MIP-1 $\beta$ ) that resist harsh physicochemical conditions in vitro ( $\mathrm{pH}$ and temperature), while maintaining functionality. These bio-functional materials are produced in recombinant cell factories through cost-effective and fully scalable processes. Notably, we demonstrate their prophylactic potential in vivo showing they protect zebrafish from a lethal infection by Pseudomonas aeruginosa.
\end{abstract}

Key words: cytokines, immunization, zebrafish, macrophages, inclusion bodies, nanoparticles.

Running title: Nanostructured cytokines as stable immunostimulants or adjuvants 


\section{Introduction}

In the quest for safe, effective, practical prophylactics and therapeutics, recombinant proteins are provoking wide interest. Prophylactics such as subunit vaccines or therapeutics such as immunostimulants, are examples of successfully produced proteins. Both are functionally well-characterized products, which are superior to DNA vaccines or inactivated/attenuated vaccines in terms of biosafety. Additionally, they are poorly reactogenic and can be designed a la carte [1]. Heterologous protein expression systems allow for easy and highly reproducible protein production at lower cost and at large scale [2]. Such systems have been developed in bacteria (E. coli), yeast (S. cerevisiae), insect cells (D. melanogaster cells), protozoa (Tetrahymena thermophila), mammalian cell cultures or plants $[3,4]$. In bacterial expression systems, in many cases, the desired protein product needs to be extracted from inclusion bodies (IBs) and renaturalized to obtain the soluble form. Recently IBs, per se, have attracted interest as bio-materials due to their high stability, withstanding extreme temperatures and lyophilization [5]. IBs are protein clusters in the upper size of the nanoscale, ranging from 50 to $700 \mathrm{~nm}$ [6], highly enriched with the recombinant protein itself but complex in composition, including a spectrum of macromolecules from the producing cell. Nevertheless, IBs are not inert and when exposed to mammalian cells penetrate the membrane and they issue a sustained release of the protein they are comprised of, in a functional form, over time [7]. This fact has been previously demonstrated with a diversity of proteins forming IBs, including hormones, chaperones, enzymes, growth factors and cytoskeleton components [7-10]. Most of the biological and physicochemical properties of IBs are moldable, such as size, bio-adhesiveness, net charge, density and the release of functional protein inside cells upon exposure [5, 11-13]. Importantly, the recombinant protein production of IBs is fully scalable and the biofabrication process is cost-effective.

Cytokines are proteins with a central role in immunity [14] and have been used as adjuvants, immunostimulants and therapeutic agents in the treatment of human diseases [15-17]. Their biomedical use is associated to their involvement in the pathogenesis of many diseases; the fact that they are unlikely to elicit an allergic response and that they are able to stimulate the immune system without the presence of a pathogen. Different cytokines have been tested as treatments for various diseases. Interferon alpha (IFN $\alpha$ ) is one of the best characterized cytokines for human disease treatment [18] and can be naturally derived (leukocyte or lymphoblastoid derived) or recombinantly produced ( $E$. 
coli-derived). Therapeutic uses of IFN $\alpha$ include hepatitis B and C (antiviral), condyloma (immunomodulation), Kaposi's sarcoma (antiangiogenic) and hairy cell-leukemia (antitumor) [17, 18]. IL-2 is another example of a cytokine that has been obtained from E. coli and evaluated as a therapeutic in bladder carcinoma and melanoma [16, 17]. TNF $\alpha$ has been produced recombinantly in E. coli and different studies have revealed it exhibits antitumor properties and strong hemodynamic effects. In fact, TNF $\alpha$ has been used to treat cancer in phase III studies in melanoma patients [19]. CCL4 induces monocyte cell recruitment at inflammatory sites [20] but clinical studies are still being conducted to confirm the pathophysiological role of CCL4 as an active factor in ischaemic stroke, as a neuroprotective agent or as an anti-HIV agent [21, 22]. Additionally, other cytokines have been explored as a potential therapeutics, such as CCL5, IL-6, IL-7, IL-15, IFN $\beta$ [23-25] but only a few recombinant cytokines such as G-CSF, GM-CSF, erythropoietin or IL-2 have been licensed for human use [1, 26]. Despite all their appealing therapeutic properties, cytokines have significant drawbacks for medical use, in particular their short half-life (minutes or hours), which implies the administration of high doses, prompting toxicity and systemic effects as cytokines are administrated intravenously. Further, high doses entail the expensive production of large quantities [27, 28].

In this study, we have explored the ability of tumor necrosis factor alpha (TNF $\alpha)$ and chemokine (C-C motif) ligand 4 (CCL4) produced as nanostructured functional IBs, to act as immunostimulants and potential adjuvants. By using cytokines in the form of nanostructured IBs, we hope to overcome the fundamental difficulties of poor stability and short half-life, which hinder cytokine use. We show that nanostructured recombinant cytokines are easy to produce by cost-effective and highly reproducible procedures. Furthermore, we provide detailed evidence in the model organism zebrafish (Danio rerio), that they can be used in vivo as efficient immunostimulants or adjuvants, either injected or orally administrated, inducing excellent immune protection levels against an otherwise lethal bacterial challenge.

\section{Materials and Methods}

\section{Bacterial strains and plasmids}

Trout CCL4 sequence (acc. number AY561709.1) was used to design specific cloning primers (Suppl. Table 1). The CCL4 full length was amplified from cDNA synthesized 
from trout head kidney total RNA purified using TriReagent (Sigma). The PCR product was excised from the gel, ligated into pET-30Xa/LIC vector (Novagen) and transformed into E. coli DH5a (Invitrogen). The CCL4-pET-30 Xa/LIC was then purified using the Nucleo-Spin Plasmid Quick-Pure (Macherey-Nagel), quantified using a Nanodrop ND-1000 (Thermo Scientific) and sequenced in order to check the sequence orientation. Finally, for recombinant protein expression the CCL4-pET-30Xa/LIC was subcloned into E. coli BL21(DE3) pLysS strain. The bacterial strain used for the production of TNFa IBs was E. coli M15[pREP4] (Qiagen). This strain was transformed with the TNF $\alpha$-pQE30 vector (Qiagen) as described [29]. CCL4-pET-30Xa/LIC and iRFP-H6pET22b were transformed into E. coli BL21(DE3) for the recombinant production of $\mathrm{IB}^{\mathrm{CCL} 4}$ and infrared fluorescent protein, $\mathrm{IB}^{\mathrm{iRFP}-\mathrm{H} 6}$ respectively. Note that $\mathrm{IB}^{\mathrm{iRFP}-\mathrm{H} 6}$ were produced as control nanoparticles with irrelevant biological activity regarding immunostimulation. All the recombinant proteins contained a His-tag and could be detected by western blot using an anti-His tag antibody (GenScript).

\section{IBs production, purification and fluorescent labelling}

The E. coli transformed with TNF $\alpha$-pQE30, CCL4-pET-30 Xa/LIC and iRFP-H6pET22b were cultured in LB medium supplemented with required antibiotics. Expression was induced when $\mathrm{OD}_{550 \mathrm{~nm}}$ reached 0.5 for $3 \mathrm{~h}$ at $1 \mathrm{mM}$ of IPTG (Panreac). For IB purification the bacterial cultures were processed through a combination of enzymatic and mechanical disruption. First, lysozyme at $1 \mu \mathrm{g} / \mathrm{ml}$ (Roche) and PMSF at $0.4 \mathrm{mM}$ (Roche) were added to bacterial suspensions and incubated for $2 \mathrm{~h}$ at $37^{\circ} \mathrm{C}$ and $250 \mathrm{rpm}$. Then, the cells were frozen and thawed and Triton X-100 (Sigma) was added $(0.2 \%(\mathrm{v} / \mathrm{v}))$, the suspension was incubated $1 \mathrm{~h}$ under gentle agitation at RT. IBs were harvested by centrifugation and resuspended in PBS (10 times concentrated with respect to the original culture volume). Next, samples were incubated with DNAse at $0.6 \mu \mathrm{g} / \mathrm{ml}$ (Roche), $1 \mathrm{~h}$ at $37^{\circ} \mathrm{C}$ under agitation. Several freeze/thaw cycles were carried out until no viable bacteria were detected. Samples were centrifuged at $15.000 \times \mathrm{g}$ for $15 \mathrm{~min}$ and pellets containing purified IBs stored at $-80{ }^{\circ} \mathrm{C}$ until use. The IBs were quantified by western blot using an anti-His-tag antibody and the protein concentration was inferred from a standard curve made with recombinant protein.

To visualize IB $^{\mathrm{TNF} \alpha}$ and $\mathrm{IB}^{\mathrm{CCL} 4}$ by flow cytometry and confocal microscopy, Atto-488 NHS ester (Sigma) was conjugated at a molar ratio 1:2 (protein/dye) following 
manufacturer's instructions. Labeling efficiency was calculated using Nanodrop ND-1000.

$I B^{T N F \alpha}$ and $I B^{C C L 4}$ nanoparticle characterization

$\mathrm{IB}^{\mathrm{TNF} \alpha}$ and $\mathrm{IB}^{\mathrm{CCL} 4}$ were characterized by Field Emission Scanning Electron Microscopy (FESEM, Zeiss Merlin). The samples were resuspended in distilled water at a final concentration of $100 \mu \mathrm{g} / \mathrm{ml}$ and $20 \mu \mathrm{l}$ were deposited on silicon chips and air dried $\mathrm{O} / \mathrm{N}$. FESEM images were processed using the software ImageJ software v1.5 (National Institute of Health, USA) length measures of at least 300 particles per sample were taken and size distribution graphs were generated using Past3 software v3.03 (University of Oslo). Particle stability was evaluated under the same conditions found in the trout gastrointestinal tract [30]. The $\mathrm{IB}^{\mathrm{TNF} \alpha}$ at $0.5 \mathrm{mg} / \mathrm{ml}$ were incubated in PBS at $\mathrm{pH} 2.5$ (adjusted with $\mathrm{HCl}$ ) for $3 \mathrm{~h}$ and then in $\mathrm{PBS}$ at $\mathrm{pH} 8.0$ (adjusted with $\mathrm{NaOH}$ ) for $6 \mathrm{~h}$ at RT under orbital shaking. Particle thermostability was also evaluated at high temperature. The $\mathrm{IB}^{\mathrm{TNF} \alpha}$ at $0.5 \mathrm{mg} / \mathrm{ml}$ were incubated at $100{ }^{\circ} \mathrm{C}$ for 30 seconds. Finally, we analyzed the stability of TNF $\alpha$ IBs after lyophilization and storage at room temperature. $\mathrm{IB}^{\mathrm{TNF} \alpha}$ were lyophilized in a Telstar Lyoquest-80 lyophilizer for $8 \mathrm{~h}$ at $-80^{\circ} \mathrm{C}$ and stored at RT for 3 weeks. The $\mathrm{IB}^{\mathrm{TNF} \alpha}$ were analyzed by FESEM and the diameter and length of 300 nanoparticles were measured. Statistical differences were analysed using a t-test (GraphPad Prism software v5, USA).

\section{Cell Cultures}

Zebrafish ZFL cells (CRL-2643, ATCC) were cultured in DMEM 4.5 g/l glucose (Gibco), $0.01 \mathrm{mg} / \mathrm{ml}$ insulin, $50 \mathrm{ng} / \mathrm{ml}$ EGF, 5 \% (v/v) of antibiotic/antimycotic, $10 \%$ $(\mathrm{v} / \mathrm{v})$ heat inactivated FBS and $0.5 \%(\mathrm{v} / \mathrm{v})$ heat-inactivated rainbow trout serum at $28{ }^{\circ} \mathrm{C}$ and $5 \% \mathrm{CO}_{2}$ as described before [31]. Adherent rainbow trout head kidney macrophages (RT-HKM) were isolated from head kidney as described previously [29] and cultured in DMEM $4.5 \mathrm{~g} / \mathrm{l}$ glucose supplemented with FBS (10 \%) and $50 \mu \mathrm{g} / \mathrm{ml}$ Primocin (Invivogen) at $16{ }^{\circ} \mathrm{C}$ and $5 \% \mathrm{CO}_{2}$. Fully differentiated macrophages (day 5) were used for uptake and gene expression experiments.

\section{Gene expression analysis}

Rainbow trout macrophages (RT-HKM) were stimulated for $12 \mathrm{~h}$ with IB $^{\text {iRFP-H6 }}$ (10 $\mu \mathrm{g} / \mathrm{ml})$, LPS $10 \mu \mathrm{g} / \mathrm{ml}$ (Sigma), $\mathrm{IB}^{\mathrm{TNF} \alpha}$ and IB ${ }^{\mathrm{CCL} 4}$ at different concentrations (5, 10 
and $20 \mu \mathrm{g} / \mathrm{ml}$ and $0.01,0.1$ and $1 \mu \mathrm{g} / \mathrm{ml}$, respectively). Total RNA was extracted using TriReagent (Sigma) following manufacturer's instructions and the RNA concentration and quality were evaluated using the Nanodrop ND-1000 and the Bioanalyser-2100 with the RNA 6000 Nano Kit (Agilent Technologies) respectively. The cDNA synthesis was performed with $1 \mu \mathrm{g}$ of total RNA using SuperScript III reverse transcriptase (Invitrogen) and oligo-dT $\mathrm{d}_{15}$ primer (Promega). Quantitative real-time PCR was carried out using SYBR Green I PCR Supermix (Bio-Rad), $250 \mathrm{nM}$ of primers and $2.5 \mu \mathrm{l}$ of cDNA previously diluted (1:50 for target and 1:500 for the reference gene) in $10 \mu \mathrm{l}$ of final volume. The primers included in the study are listed in Supplementary Table 1. Elongation factor 1 alpha (EF1 $\alpha)$ was used as a reference gene and quantification was done according to Livak method [32]. The experiments were repeated 3 independent times and all samples were run in triplicate. The results were analyzed using one-way ANOVA followed by Tukey’s post-test (GraphPad Prism).

IBs uptake by ZFL and RT-HKM cells

Fluorescent $\mathrm{IB}^{\mathrm{TNF} \alpha}$ and $\mathrm{IB}^{\mathrm{CCL} 4}$ were added to the ZFL and RT-HKM cell cultures at the indicated doses and time, and the cells were analyzed by flow cytometry (BD FACSCanto) and confocal microscopy (Zeiss LSM 700). For the dose-response uptake assays, the ZFL and RT-HKM cells were incubated with $\mathrm{IB}^{\mathrm{TNF} \alpha}$ and $\mathrm{IB}^{\mathrm{CCL} 4}$ at different doses (5, 10 and $20 \mu \mathrm{g} / \mathrm{ml}$ ) for $12 \mathrm{~h}$. After treatment, the medium was removed and the cells were washed with PBS to remove membrane bound particles. Each sample was treated with 1 $\mathrm{mg} / \mathrm{ml}$ trypsin (Gybco) for $15 \mathrm{~min}$ to discard externally attached IBs and then centrifuged at $300 \mathrm{x} \mathrm{g}$ for $5 \mathrm{~min}$. Pellets were resuspended in $200 \mu \mathrm{l}$ of PBS for flow cytometry analysis. Experiments were performed in triplicate and 10,000 events for each sample were taken. The results were analyzed with one-way ANOVA and a Tukey's post-test. For confocal microscopy, the ZFL and RT-HKM cells were incubated with $20 \mu \mathrm{g} / \mathrm{ml}$ of $\mathrm{IB}^{\mathrm{TNF} \alpha}$ and $\mathrm{IB}^{\mathrm{CCL} 4}$ for $12 \mathrm{~h}$. After three PBS washes, the nuclei were labeled with Hoechst $33342(10 \mu \mathrm{g} / \mathrm{ml})$ and the membranes with CellMask (5 $\mu \mathrm{g} / \mathrm{ml})$. The images were analyzed with Imaris software v8.1 (Bitplane AG).

\section{Animals}

Adult wild-type zebrafish (Danio rerio) and rainbow trout (O. mykiss) were maintained

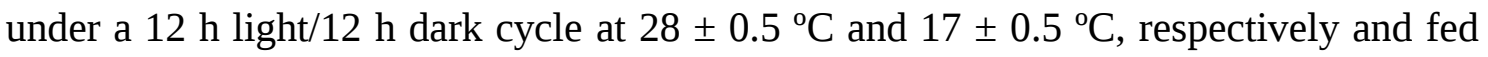
daily with a commercial diet at $0.5 \%$ ratio. All experimental procedures were approved 
by to the Ethical Committee of the Universitat Autònoma de Barcelona (Reference 1555) in agreement with the International Guiding Principles for Biomedical Research Involving Animals (EU 2010/63).

In vivo biodistribution of $I B^{T N F \alpha}$ in rainbow trout

Animals (122.3 \pm 17.13 g body weight) were anesthetized and i.p. injected with $300 \mu l$ of IB ${ }^{\mathrm{TNF}}$-Atto488 (5.5 mg/kg) or $300 \mu \mathrm{l}$ of PBS. After 24, 48 and $72 \mathrm{~h}$ fish $(\mathrm{n}=4)$ were sacrificed by overdose of MS-222 (Sigma) and head kidney and spleen were removed. Adherent monocytes/macrophages were isolated from head kidney and spleen as described before [29]. In parallel, a piece of tissue was dissected and stored at $-80{ }^{\circ} \mathrm{C}$ for gene expression analysis. After $24 \mathrm{~h}$ of primary cell culture, cells were analyzed both by flow cytometry and confocal microscopy.

In vivo immunization with TNF $\alpha$ and CCL4 IBs

Adult zebrafish (0.64 \pm 0.17 g body weight) were transferred to an isolated system and acclimatized 1 day before each experiment. Pseudomonas aeruginosa (PAO1) was cultured and grown as previously described [33]. For IBs and PAO1 injection, fish were anaesthetized with 166 ppm of MS-222 (Sigma) and intraperitoneally (i.p) injected with either $20 \mu \mathrm{l}$ of IBs or PBS. At 7 or 30 days post-injection, fish were challenged by i.p. injection with $20 \mu \mathrm{l}$ of $P$. aeruginosa PAO1 $\left(\mathrm{LD}_{50}\right)$ at $4 \times 10^{7} \mathrm{cfu} / \mathrm{animal}$ and their survival was followed for 7 days. Survival curves were analyzed using the KaplanMeier method and the differences were evaluated using the log-rank test (GraphPad Prism). Relative percentage of survival (RPS) was calculated according to RPS (\%) = [(1 - mortality treated group $) /$ mortality control group $] \times 100$.

\section{Oral administration of TNF $\alpha$ IBs}

Rainbow trout $(135.3 \pm 16.8$ g body weight) were starved three days before the administration of the IBs. Then, animals were anesthetized, orally intubated and $200 \mu \mathrm{l}$ of $\mathrm{IB}^{\mathrm{TNF} \alpha}$-Atto488 $(7.49 \pm 0.97 \mathrm{mg} / \mathrm{kg})$ were administrated. After $24 \mathrm{~h}$ rainbow trout were sacrificed by overdose of anesthesia and the intestine was removed and maintained in DMEM. The intestine was divided in three sections: pyloric caeca, midgut and hindgut (hindgut section was discarded). Cells from the intestine were obtained by enzymatic digestion with collagenase $(0.15 \mathrm{mg} / \mathrm{ml}$, Invitrogen) for $2 \mathrm{~h}$ at RT. After digestion, the intestine pieces were mechanically disrupted with a cell strainer and the 
resulting homogenate was centrifuged $15 \mathrm{~min}$ at $450 \mathrm{x} \mathrm{g}$ at $4{ }^{\circ} \mathrm{C}$. Then, the pellet was washed, resuspended in DMEM and analyzed by flow cytometry $(100,000$ events/sample). Additionally, pyloric caeca and midgut samples $(n=6)$ were embedded in Tissue-Tek O.C.T. Compound (Sakura), frozen and stored at $-80{ }^{\circ}$ C. Sections of $0.6 \mu \mathrm{m}$ were obtained at $-20{ }^{\circ} \mathrm{C}$ with a Cryostat (Leica CM3050S). Fluoroshield (Sigma) was added to every slide and all samples were analyzed by confocal microscopy.

\section{Results}

1. Structural characterization of TNF $\alpha\left(\right.$ IB $\left.^{\mathrm{TNF} \alpha}\right)$ and CCL4 (IB $\left.{ }^{\mathrm{CCL} 4}\right)$ IBs.

Two different cytokines, CCL4 and TNFa, were successfully produced in E. coli as IBs (Figure 1A). The morphology and size of both biomaterials were characterized by FESEM and are shown in Figure 1A. The shape of the IBs differs between the two cytokines. $\mathrm{IB}^{\mathrm{TNF} \alpha}$ is cylindrical with a smooth surface and several circular pores, and $\mathrm{IB}^{\mathrm{CCL} 4}$ is also spherical but with a more irregular surface. Similar morphology has been described previously for other protein nanoparticles purified from IBs [11]. The size of $\mathrm{IB}^{\mathrm{TNF} \alpha}$ and $\mathrm{IB}^{\mathrm{CCL} 4}$ also differed significantly. $\mathrm{IB}^{\mathrm{TNF} \alpha}$ diameter was between 380 to $900 \mathrm{~nm}$ with a mean size of $623.3 \pm 105 \mathrm{~nm}$ and length ranging between 750 to $2000 \mathrm{~nm}$ with a mean length of $1134.6 \pm 196.6 \mathrm{~nm}$ (Figure $1 \mathrm{~B}$ (i -ii)). The IB ${ }^{\text {CCL4}}$ have a smaller size ranging between 220 to $850 \mathrm{~nm}$ with a mean size of $383.9 \pm 82.3 \mathrm{~nm}$ (Figure 1B (i)). Furthermore, the purified IB yield varied between proteins under the same production conditions; we obtained 18 times more IB $^{\text {TNF } \alpha}$ than IB $^{\text {CCL4 }}$ (18 $\pm 5 \mathrm{mg} / \mathrm{l}$ and $1.2 \pm 0.92 \mathrm{mg} / \mathrm{l}$, respectively).

2. Uptake of IB ${ }^{\mathrm{TNF} \alpha}$ and $\mathrm{IB}^{\mathrm{CCL} 4}$ by ZFL and RT-HKM

To explore the interaction of these IBs with cells, we analyzed the uptake of IB ${ }^{\mathrm{TNF} \alpha}$ and $\mathrm{IB}^{\mathrm{CCL} 4}$ by zebrafish liver cells (ZFL) and by trout primary macrophages (RT-HKM). The results showed that ZFL cells were able to uptake both $\mathrm{IB}^{\mathrm{TNF} \alpha}$ and IB ${ }^{\mathrm{CCL} 4}$ very efficiently (Figure 2A) and the dose-response assays showed that all concentrations of IB $^{\mathrm{TNF} \alpha}$ and IB $^{\text {CCL4 }}$ were easily endocyted by ZFL cells (e.g. $97 \pm 0.5 \%$ and $99 \pm 0.1 \%$ positive cells at $10 \mu \mathrm{g} / \mathrm{ml}$, respectively) (Figure 2A). Also primary cultures of macrophages (RTHKM) were able to uptake the $\mathrm{IB}^{\mathrm{TNF} \alpha}$ and $\mathrm{IB}^{\mathrm{CCL} 4}$ at the same levels as ZFL cells (96 \pm $1.4 \%$ and $98 \pm 0.9 \%$ positive cells at $10 \mu \mathrm{g} / \mathrm{ml}$, respectively) (Figure 3A). When we analysed the Mean Fluorescence Intensity (MFI) of the dose response experiments we 
observed a good correlation between IB dose and MFI both in ZFL and HKM cells (Supp. Figure 1). Finally, the confocal microscopy images enabled the visualization of the uptake by ZFL and the RT-HKM cells (Figure 2B and 3B (i)) and the 3D images demonstrated the complete internalization of IBs in ZFL and in RT-HKM (Figure 2B and 3B (ii - iv)).

\section{Bioactivity of $\mathrm{IB}^{\mathrm{TNF} \alpha}$ and IB $\mathrm{BB}^{\mathrm{CCL} 4}$}

In order to evaluate the capacity of IBs to activate the immune response in specific immune cells, we stimulated trout macrophages (RT-HKM) with $\mathrm{IB}^{\mathrm{TNF} \alpha}$, with $\mathrm{IB}^{\mathrm{iRFP}-\mathrm{H} 6}$ as a control of an IB without a relevant immune role, and with LPS as a typical strong activator of the immune response [34]. $\mathrm{IB}^{\mathrm{TNF} \alpha}$ were able to stimulate RT-HKM by increasing the gene expression of cytokines and regulators of inflammation. We showed that treatment with $\mathrm{IB}^{\mathrm{TNF} \alpha}$ stimulated the expression of pro-inflammatory cytokines such as TNF $\alpha$, IL-6, IL-1 $\beta$ and IL-8 (Figure 4). We also analyzed genes related to the modulation of the inflammation process, the inhibition of the cytokine receptor signaling and the extracellular matrix remodeling, such as COX-2, CAMP-1, SOCS3 and MMP9. The results showed that $\mathrm{IB}^{\mathrm{TNF} \alpha}$ were able to increase the expression of these genes at different $\mathrm{IB}^{\mathrm{TNF} \alpha}$ concentrations, but not in a dose-dependent manner (Figure 4). We did not observe an effect related to the sequence of the protein forming IBs, at least there were no differences in the gene expression between $\mathrm{IB}^{\mathrm{TNF} \alpha}$ and $\mathrm{IB}^{\mathrm{iRFP}-\mathrm{H} 6}$ treatments. However, $\mathrm{IB}^{\mathrm{TNF} \alpha}$ were able to induce an increase in gene expression comparable to that of commercial LPS. Similar results were obtained when we stimulated RT-HKM with $\mathrm{IB}^{\mathrm{CCL} 4}$ but at lower doses. The results showed that the $\mathrm{IB}^{\mathrm{CCL} 4}$ were able to induce expression of all the genes analyzed and gene expression was significantly different from LPS and IB ${ }^{\mathrm{iRFP}-\mathrm{H} 6}$ for IL-6, SOCS3 and CAMP1 (Suppl. Figure 2), indicating that the nature of the protein had an effect on the immunostimulation. However, this event could not be observed in other genes: TNF $\alpha$, IL-1 $\beta$, IL-8, COX-2 and MMP9.

\section{In vivo biodistribution of $\mathrm{IB}^{\mathrm{TNF} \alpha}$}

Next, to study whether or not macrophages were the targets of the $\operatorname{IB}^{\mathrm{TNF} \alpha}$ in vivo we injected animals with $\mathrm{IB}^{\mathrm{TNF}}$-Atto488 IBs. In these experiments we decided to work only with $\mathrm{IB}^{\mathrm{TNF} \alpha}$ since, as mentioned before, the yield of $\mathrm{IB}^{\mathrm{TNF} \alpha}$ was higher than that of IB ${ }^{\mathrm{CCL} 4}$ and this enabled us to do the in vivo experiments. Worth to mention that due to the small size of zebrafish, that did not allow us to perform this kind of in vivo biodistribution 
experiments, we used another teleost (trout) thus maintaining the physiological and immunological coherence. By flow cytometry, fluorescent cells were significantly detected in spleen at 48, 72 and 96 h post-injection (Figure 5A). Fluorescent positive cells were also found in phagocytes in the head kidney at the same time points (Figure 5A), although at lower levels than in the spleen (e.g. at $48 \mathrm{~h}$ post-injection, the percentage of fluorescent cells in the spleen was $78 \pm 7.5 \%$ while in the head kidney was $22.9 \pm 2.4 \%$ ). The total number of fluorescent cells detected both in spleen and head kidney decreased along the time (Figure 5A) although they could be detected at least until 10 days after the injection (data not shown). The presence of $\operatorname{IB}^{\mathrm{TNF} \alpha}$ in macrophages in both immune organs was also detected by confocal microscopy at 48 , 72 and 96 h post-injection (Figure 5B and 5C (i)). Again, the number of IB $^{\mathrm{TNF} \alpha}$ positive macrophages in head kidney was lower than in phagocytes from the spleen (Figure 5B and 5C (i)). The complete internalization of the nanoparticles and their location in the cytoplasm of the cells was demonstrated with z-stack and membrane staining in macrophages from spleen and head kidney (Figure 5B and 5C (i - iii)).

\section{In vivo immunization with $\mathrm{IB}^{\mathrm{TNF} \alpha}$ and $\mathrm{IB}^{\mathrm{CCL} 4}$.}

We next evaluated whether the $\mathrm{IB}^{\mathrm{TNF} \alpha}$, $\mathrm{IB}^{\mathrm{CCL} 4}$ and $\mathrm{IB}^{\mathrm{iRFP}-\mathrm{H} 6}$ were able to protect against a model lethal challenge with $P$. aeruginosa. We obtained higher survival rates in fish treated with $\mathrm{IB}^{\mathrm{TNF} \alpha}$ and $\mathrm{IB}^{\mathrm{CCL} 4}$ compared to those animals treated with $\mathrm{IB}^{\text {iRFP-H6 }}$ containing a control protein (100 \% RPS of $\mathrm{IB}^{\mathrm{TNF} \alpha}$ and $91 \%$ RPS of IB ${ }^{\mathrm{CCL} 4}$ ) (Figure 6A (i - ii)). Interestingly, the protection levels achieved with IB $^{\text {CCL4 }}$ were significantly higher at half of the dose of $\mathrm{IB}^{\mathrm{TNF} \alpha}$ (Figure 6B (ii)). The high viscosity of IB ${ }^{\mathrm{CCL} 4}$ solution did not allow us to use this IB at the highest dose, however with a quarter of the IB ${ }^{\text {TNFo }}$ dose we obtained excellent protection levels (survival of $91 \%$ with IB ${ }^{\text {CCL4 }}$ at $75 \mu \mathrm{g}$ compared with survival of $100 \%$ with $\mathrm{IB}^{\mathrm{TNF} \alpha}$ at $300 \mu \mathrm{g}$ ) and these differences were still observed at a lower dose $\left(150 \mu \mathrm{g}\right.$ of $\mathrm{IB}^{\mathrm{TNF} \alpha}$ ) (Figure 6B (i)). When we compared the survival obtained with the $\mathrm{IB}^{\mathrm{iRFP}-\mathrm{H} 6}$ treatment (non-immunologically relevant protein), the results showed significant differences with both cytokine IBs treatments (IB ${ }^{\mathrm{TNF} \alpha}$, $p<0.01$ and IB ${ }^{\text {CCL4 }}, p<0.05$ ) (Figure 6). Finally, to demonstrate that cytokines and not $E$. coli contaminants such as endotoxin, peptidoglycans or nucleic acids, were the main responsibles of immune activation we performed the bacterial challenge 30 days after the injection of $\mathrm{IB}^{\mathrm{TNF} \alpha}$ (Suppl. Figure 3) when the early innate immune response is not active and the observed increased in the survival, relays only on the adaptive immune 
response. We observed that the survival was clearly higher in the animals injected with the $\mathrm{IB}^{\mathrm{TNF} \alpha}$ (75 \% RPS) 30 days after the treatment with the $\mathrm{IB}^{\mathrm{TNF} \alpha}$ (Suppl. Figure 3).

\section{In vitro stability tests of $\mathrm{IB}^{\mathrm{TNF} \alpha}$}

It is well documented that the IBs are stable in vitro under a wide range of conditions, for example: at different temperatures $\left(-80^{\circ} \mathrm{C}, 4^{\circ} \mathrm{C}, 25^{\circ} \mathrm{C}\right.$, and $\left.37^{\circ} \mathrm{C}\right)$ or under lyophilization conditions $\left(12 \mathrm{~h}\right.$ at $\left.-80^{\circ} \mathrm{C}\right)$ [5]. Since we also wanted to test their suitability for oral administration, we determined IB stability under gastrointestinal $\mathrm{pH}$ conditions [30]. We also tested thermostability to demonstrate stable shelf life (high temperature and lyophilization). In general, we observed a similar shape of IB $^{\mathrm{TNF} \alpha}$ under different $\mathrm{pH}$ or the temperature treatments compared to untreated control (Figure 7A and B) and a similar diameter and length distribution between control and $\mathrm{pH}$ treatment (Figure 7A (ii - iii)). We only found significant differences in the diameter and length between the high temperature (diameter: $666.2 \pm 84.2 \mathrm{~nm}$, t- test, $p<0.0001$; length: $947.1 \pm 186.4 \mathrm{~nm}$, t- test, $p<0.0001$ ) and the control condition (diameter: $623.3 \pm 105$ nm; length: $1134.6 \pm 196.6 \mathrm{~nm}$ ) (Figure 7B (ii - iii)). To further explore why the temperature was shortening the IBs, we checked the presence of protein in the supernatants of samples submitted to high temperature. The western blot confirmed that free/soluble protein was not present in the supernatants (data not shown) discarding our hypothesis of a potential massive release of protein from the nanostructure due to the drastic environmental change. Despite the size differences in the IBs incubated a high temperature, both IBs submitted to $\mathrm{pH}$ and temperature treatments were still able to stimulate the gene expression of immune related genes at equivalent levels to the same IBs under control conditions (Suppl. Figure 4). We also evaluated whether fluorescent $\mathrm{IB}^{\mathrm{TNF} \alpha}$ were able to maintain their fluorescence after incubation at low/high $\mathrm{pH}$. As shown in Figure 7C, the RT-HKM were able to endocytose the $\mathrm{pH}$ treated $\mathrm{IB}^{\mathrm{TNF}}$ Atto488 IBs without differences with respect to control. Importantly, fluorescence intensity remained the same after the $\mathrm{pH}$ treatment, which would allow us to monitor fluorescent TNF $\alpha$ materials administrated orally. Finally, we analyzed the stability of $\mathrm{IB}^{\mathrm{TNF} \alpha}$ after lyophilization, showing that this procedure did not modify the morphology as shape, size and porosity were maintained (Suppl. Figure 5A and 5B (i-ii)). Lyophilization did not affect the ability of the $\mathrm{IB}^{\mathrm{TNF} \alpha}$ to protect animals against a $P$. aeruginosa lethal challenge and animals injected with lyophilized and non-lyophilized 
$\mathrm{IB}^{\mathrm{TNF} \alpha}$ survived without a significant difference between treatment groups (83\% of RPS and $62 \%$ of RPS, respectively) (Figure 7D).

\section{Oral administration of fluorescent $\mathrm{IB}^{\mathrm{TNF} \alpha}$}

First we demonstrated in vitro excellent mechanical and functional stability properties of the $\mathrm{IB}^{\mathrm{TNF} \alpha}$ under those conditions mimicking the traffic through the gastrointestinal tract. Next, we tested in vivo whether the orally administrated $\mathrm{IB}^{\mathrm{TNF} \alpha}$ could reach the mucosal tissue and the cells within the intestinal mucosa. We intubated adult animals and we administrated $\mathrm{IB}^{\mathrm{TNF} \alpha}$-Atto488 IBs into the stomach. After $24 \mathrm{~h}$ we dissected the intestine to perform cytometry and tissue sections. We worked with the pyloric caeca and the midgut segments as they are the main areas of nutrient absorption [35]. To perform the flow cytometry analysis we pooled the cells from the pyloric caeca and the midgut and we detected $20.2 \pm 7.4 \%$ of fluorescent cells (Figure $8 \mathrm{~A}$ ). This is a high percentage considering that no cell type was separated by other means such as specific antibody labeling and cell sorting [36]. The tissue sections allowed the visualization of the IB ${ }^{\mathrm{TNF}}$-Atto488 IBs both in cells of the pyloric caeca and cells of the midgut (Figure $8 \mathrm{~B})$. In the pyloric caeca the presence of $\mathrm{IB}^{\mathrm{TNF} \alpha}$-Atto488 IBs was qualitatively more abundant than in the midgut sections. The positive cells in the pyloric caeca were mainly located in the villi base and in the submucosa, while in the midgut sections the $\mathrm{IB}^{\mathrm{TNF} \alpha}$-Atto488 IBs were mainly observed in the villi apex and in the lamina propria (Figure 8B (ii-iii)). The IBs detected in the intestinal mucosa were able to form intracellular agglomerates of different sizes in the cytosol both in the pyloric caeca and midgut sections (Figure 8B).

\section{Discussion}

We have used two model cytokines and a model organism to test whether cytokine nanoparticles organized as functional IBs were suitable as immunostimulants or adjuvants for biomedical applications. In this work, we provide a proof of concept on the functionality and suitability of protein nanoparticles for their future possible use in human health. IBs are excellent candidates to be used as adjuvants, being highly stable, non-toxic and fully biocompatible under a wide range of conditions [7]. As shown in this study, $\mathrm{IB}^{\mathrm{TNF} \alpha}$ maintained its stability and functionality after incubation under different conditions of $\mathrm{pH}$ and temperature, supporting the notion that IBs made of 
recombinant cytokines do not require additional encapsulation systems, since they are extremely stable in the nanostructured conformation. This is in sharp contrast to immunostimulants made with native cytokines that are extremely unstable (half-life of minutes). Indeed, when oral administration of such vaccines is desired, often the design has to include additional nanoencapsulation systems that provide protection under in vivo conditions [37, 38]. A variety of encapsulation methods, to protect vaccines or cytokines against degradation in the intestinal tract have been reported with promising results but, in most cases they are not yet cost effective [37, 39]. As IBs, cytokines are not only structurally stable, but they maintain their functional properties intact. Both of our prophylactic IBs, $\mathrm{IB}^{\mathrm{TNF} \alpha}$ and $\mathrm{IB}^{\mathrm{CCL} 4}$, were able to induce a typical immune response in vitro and were also able to efficiently protect zebrafish from a lethal bacterial infection. In this study we have obtained higher survival percentages when injecting IBs made with immune-relevant proteins. In fact, the main responsible of the protection observed when injected $\mathrm{IB}^{\mathrm{TNF} \alpha}$ is the nanostructured cytokine as has been demonstrated in the long-term protection experiments. However, the protection conferred by the IBs is probably the result of their nanostructure, the sequence of the building protein, combined with their compositional complexity (LPS, lipids, PGN and nucleic acids). The high protection levels of $\mathrm{IB}^{\mathrm{CCL} 4}$ at a lower dose compared to that of $\mathrm{IB}^{\mathrm{TNF} \alpha}$ could be due to the differential presence of co-purified bacterial components (LPS, lipids, PGN and nucleic acids) during both IBs purification procedures. $\mathrm{IB}^{\mathrm{TNF} \alpha}$ and $\mathrm{IB}^{\mathrm{CCL} 4}$ confer higher survival rates in comparison to other IBs made with non-immune relevant proteins ( $\left.\mathrm{IB}^{\mathrm{iRFP}-\mathrm{H} 6}\right)$. Importantly, the IBs final composition can be modulated using different E. coli strains (e.g. endotoxin free strains) together with "final purpose"adapted purification methods [7, 40]. Our results strongly suggest that the immunological nature of the protein increases the protection conferred by the IBs, opening the way to explore other proteins, such as antigenic viral proteins for vaccine design.

From a commercial point of view it is also important to demonstrate the feasibility of the cytokine IBs pipeline production. In this context, the IBs did not modify their structural or functional properties after lyophilization, meaning that lyophilized IBs would not require cold-chain maintenance and could be stored and used at ambient temperatures. All these characteristics lower the cost of production of the final products and provide easy and convenient handling. Both, the structural and functional stability together with versatility would be the key for a future biomedical use of cytokines 
produced as IBs. When injected, IBs were able to reach and accumulate in immune relevant-organs (spleen and head kidney) and -cells (macrophages), as reported by other authors [33, 41]. The spleen is the major filtering organ for removal of foreign agents [42] and together with head kidney, are the main lymphoid organs in teleosts [43]. In addition, these are also the organs where phagocytes are more abundant and importantly, the spleen is the main organ for antigen presentation in teleosts [44, 45]. In mammals the spleen is also the main organ of antigen removal and recognition together with the lymph nodes and the thymus [46].

Moreover, our results strongly support the view that IBs could be excellent candidates for oral administration. After oral administration IBs were clearly uptaken and located in the villi base and submucosa within the pyloric caeca section and, in the villi apex and lamina propria within the midgut. Oral immunization provokes the activation of lymphocytes $\mathrm{T}$ and $\mathrm{B}$ and the antibody production in the mucosal secretions (e.g. skin mucus, bile, intestine mucus) $[35,47]$. The main immune tissue involved in the uptake and processing of orally administrated antigens is the gut-associated lymphoid tissue (GALT). Teleosts possess the whole set of immune cells and molecules required for a GALT local immune response, although the global GALT structure is more diffuse than in mammals [48]. In teleosts the main effector sites in GALT are located in the lamina propria (LP) and in the intraepithelial lymphocyte compartments (IEL) while the classical effector sites (Peyer's patches and mesenteric lymph nodes MLNs) have only been described in mammals [49]. Fish do not have these structures but possess extrafollicular antigen presenting cells (APCs) that have been also described as inducer cells [50]. Accordingly, we detected fluorescent nanoparticles in the LP (midgut) and in the villi apex where IEL are located. The strong uptake ability of the midgut has an immune value, because it has been shown that antigens could be transported towards the local as well as systemic immune system [48, 51]. Based on our results, the IBs have been uptaken in the intestine maybe by IEL and APCs and stored intracellularly, probably stimulating mucosal immune responses. The nanostructure and stability of the IBs, together with the good levels of absorption by the intestinal mucosa favor the possibility of oral use.

\section{Conclusions}


In this study we were able to produce nanostructured, functional and highly stable cytokines as inclusion bodies (IBs), generating a fully biocompatible material with biomedical applicability, without further encapsulation needs. These cytokines, IB ${ }^{\mathrm{TNF} \alpha}$ and $\mathrm{IB}^{\mathrm{CCL} 4}$, interact with relevant immune cells and tissues both when intraperitoneally injected or orally administrated, and provide in vivo excellent protection levels against a model lethal infection. These new biomaterials pave the way for using recombinant cytokines for therapeutical purposes in a more efficient and cost effective way.

\section{Acknowledgments}

This work was supported by grants from the Spanish Ministry of Science and the Agència de Gestió d'Ajuts Universitaris i de Recerca to NR (AGL2012-33877 and AGL2015-65129-R, MINECO and 2014SGR-345) and to EGF (INIA, RTA201200028-C02-02, MINECO). The authors also acknowledge the financial support granted to AV from Agència de Gestió d’Ajuts Universitaris i de Recerca (2014SGR-132) and the Centro de Investigación Biomédica en Red de Bioingeniería, Biomateriales y Nanomedicina (CIBER-BBN) with assistance from the European Regional Development. DT was supported by CONICYT-Chile on a PhD fellowship, JSF received a post-doctoral fellowship from Asociación Española Contra el Cancer (AECC), EGF received a post-doctoral fellowship from INIA (DOC-INIA, MINECO), DP is supported by the European Commission under 7th Framework Programme of the European Union (Grant Agreement 311993 TARGETFISH) and NR is supported by the Ramón y Cajal program (RYC-2010-06210). AV has been awarded with an ICREA Academia award. We would also like to thank Rosemary Thwaite for critical reading and english correction of the manuscript and the "Servei de Microscopia" of the Universitat Autònoma de Barcelona (UAB), the Confocal Microscopy Service (INcUAB) and the Protein Production Platform (CIBER-BBN) for helpful technical assistance. 


\section{References}

1. Unnikrishnan, M.; Rappuoli, R.; Serruto, D. Recombinant bacterial vaccines. Current Opinion in Immunology 2012, 24, 337-342.

2. Zhang, N.; Zheng, B. J.; Lu, L.; Zhou, Y.; Jiang, S.; Du, L. Advancements in the development of subunit influenza vaccines. Microbes and Infection 2015, 17, 123-134.

3. Ohtake, S.; Arakawa, T. Recombinant therapeutic protein vaccines. Protein and peptide letters 2013, 20(12): 1324-1344.

4. Bill, R. M. Recombinant protein subunit vaccine synthesis in microbes: a role for yeast? J Pharm. Pharmacol. 2014, 67, 319-328.

5. Garcia-Fruitos, E.; Rodríguez-Carmona, E.; Diez-Gil, C.; Ferraz, R. M.; Vazquez, E.; Corchero, J. L.; Cano-Sarabia, M.; Ratera, I.; Ventosa, N.; Veciana, J.; Villaverde, A. Surface Cell Growth Engineering Assisted by a Novel Bacterial Nanomaterial. Adv. Mater. 2009, 21, 4249-4253.

6. Garcia-Fruitos, E.; Vazquez, E.; Diez-Gil, C.; Corchero, J. L.; Seras-Franzoso, J.; Ratera, I.; Veciana, J.; Villaverde, A. Bacterial inclusion bodies: making gold from waste. Trends Biotechnol. 2012, 30(2) 65-70.

7. Vazquez, E.; Corchero, J. L.; Burgueño, J. F.; Seras-Franzoso, J.; Kosoy, A.; Bosser, R.; Mendoza, R.; Martínez-Láinez, J. M.; Rinas, U.; Fernández, E.; Ruiz-Avila, L.; Garcia-Fruitos, E.; Villaverde, A. Functional Inclusion Bodies Produced in Bacteria as Naturally Occurring Nanopills for Advanced Cell Therapies. Adv. Mater. 2012, 24, 1742-1747.

8. Liovic, M.; Ozir, M.; Zavec, A. B.; Peternel, Š.; Komel, R.; Zupancic, T. Inclusion bodies as potential vehicles for recombinant protein delivery into epithelial cells. Microb. Cell Fact. 2012, 11, 1-1.

9. Seras-Franzoso, J.; Steurer, C.; Roldán, M.; Vendrell, M.; Vidaurre-Agut, C.; Tarruella, A.; Saldaña, L.; Vilaboa, N.; Parera, M.; Elizondo, E.; Ratera, I.; Ventosa, N.; Veciana, J.; Campillo-Fernández, A. J.; Garcia-Fruitos, E.; Vazquez, E.; Villaverde, A. Functionalization of 3D scaffolds with protein-releasing biomaterials for intracellular delivery. Journal of Controlled Release 2013, 171, 63-72.

10. Seras-Franzoso, J.; Peebo, K.; Garcia-Fruitos, E.; Vazquez, E.; Rinas, U.; Villaverde, A. Improving protein delivery of fibroblast growth factor- 2 from bacterial inclusion bodies used as cell culture substrates. Acta Biomaterialia 2014, 10, 13541359.

11. Peternel, Š.; Grdadolnik, J.; Gaberc-Porekar, V.; Komel, R. Engineering inclusion bodies for non denaturing extraction of functional proteins. Microb. Cell Fact. 2008, 7, 34.

12. Diez-Gil, C.; Krabbenborg, S.; Garcia-Fruitos, E.; Vazquez, E.; Rodríguez-Carmona, E.; Ratera, I.; Ventosa, N.; Seras-Franzoso, J.; Cano-Garrido, O.; Ferrer-Miralles, N.; Villaverde, A.; Veciana, J. The nanoscale properties of bacterial inclusion bodies and their effect on mammalian cell proliferation. Biomaterials 2010, 31, 5805-5812.

13. Seras-Franzoso, J.; Diez-Gil, C.; Vazquez, E.; Garcia-Fruitos, E.; Cubarsi, R.; Ratera, I.; Veciana, J.; Villaverde, A. Bioadhesiveness and efficient mechanotransduction stimuli synergistically provided by bacterial inclusion bodies as scaffolds for tissue engineering. Nanomedicine 2012, 7, 79-93.

14. Mosmann, T. R.; Sad, S. The expanding universe of T-cell subsets: Th1, Th2 and more. Immunology today 1997, 17, 1-9.

15. Kullberg, B. J.; van der Meer, J. Introduction: cytokines in the biotherapy of infectious diseases. Biotherapy 1994, 7, 149-150.

16. Nohria, A.; Rubin, R. H. Cytokines as potential vaccine adjuvants. Biotherapy 1994, 
7, 261-269.

17. Mire-Sluis, A. R. Cytokines: from technology to therapeutics. Trends Biotechnol. 1999, 17, 319-325.

18. Finter, N. B. Cytokines in the treatment of virus infections. Biotherapy 1994, 7, 151159.

19. Lejeune, F. J.; Liénard, D.; Matter, M.; Rüegg, C. Efficiency of recombinant human TNF in human cancer therapy. Cancer Immun. 2006, 6, 6-23.

20. Mirabelli-Badenier, M.; Braunersreuther, V.; Viviani, G. L.; Dallegri, F.; Quercioli, A.; Veneselli, E.; Mach, F.; Montecucco, F. CC and CXC chemokines are pivotal mediators of cerebral injury in ischaemic stroke. Thromb. Haemost. 2011, 105, 409420.

21. Alvarez, Y.; Tuen, M.; Shen, G.; Nawaz, F.; Arthos, J.; Wolff, M. J.; Poles, M. A.; Hioe, C. E. Preferential HIV Infection of CCR6+ Th17 Cells Is Associated with Higher Levels of Virus Receptor Expression and Lack of CCR5 Ligands. Journal of Virology 2013, 87, 10843-10854.

22. Ferre, A. L.; Hunt, P. W.; Critchfield, J. W.; Young, D. H.; Morris, M. M.; Garcia, J. C.; Pollard, R. B.; Yee, H. F.; Martin, J. N.; Deeks, S. G.; Shacklett, B. L. Mucosal immune responses to HIV-1 in elite controllers: a potential correlate of immune control. Blood 2009, 113, 3978-3989.

23. Melchionda, F.; Fry, T. J.; Milliron, M. J.; McKirdy, M. A.; Tagaya, Y.; Mackall, C. L. Adjuvant IL-7 or IL-15 overcomes immunodominance and improves survival of the CD8+ memory cell pool. J. Clin. Invest. 2005, 115, 1177-1187.

24. Scheller, J.; Chalaris, A.; Schmidt-Arras, D.; Rose-John, S. The pro- and antiinflammatory properties of the cytokine interleukin-6. Biochimica et Biophysica Acta, 2011, 1813, 878-888.

25. Lapteva, N.; Huang, X. F. CCL5 as an adjuvant for cancer immunotherapy. Expert Opinion on Biological Therapy 2010, 10, 725-733.

26. Armstrong, W. S.; Kazanjian, P. Use of cytokines in human immunodeficiency virus-infected patients: colony-stimulating factors, erythropoietin, and interleukin-2. Clin. Infect. Dis. 2001, 32, 766-773.

27. Rollwagen, F. M.; Baqar, S. Oral cytokine administration. Trends Immunology Today 1996, 17, 1-3.

28. Kornbluth, R. S.; Stone, G. W. Immunostimulatory combinations: designing the next generation of vaccine adjuvants. Journal of Leukocyte Biology 2006, 80, 1084-1102.

29. Roher, N.; Callol, A.; Planas, J. V.; Goetz, F. W.; MacKenzie, S. A. Endotoxin recognition in fish results in inflammatory cytokine secretion not gene expression. Innate Immun. 2011, 17, 16-28.

30. Sugiura, S. H. Dietary acidification enhances phosphorus digestibility but decreases

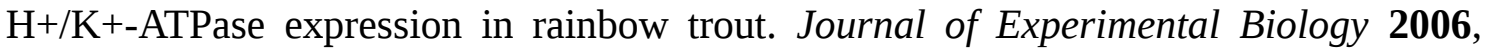
209, 3719-3728.

31. Ruyra, A.; Cano-Sarabia, M.; Mackenzie, S. A.; Maspoch, D.; Roher, N. A Novel Liposome-Based Nanocarrier Loaded with an LPS-dsRNA Cocktail for Fish Innate Immune System Stimulation. PLoS ONE 2013, 8, e76338.

32. Livak, K. J.; Schmittgen, T. D. Analysis of Relative Gene Expression Data Using Real-Time Quantitative PCR and the 2- $\Delta \Delta$ CT Method. Methods 2001, 25, 402-408.

33. Ruyra, A.; Cano-Sarabia, M.; Garcia-Valtanen, P.; Yero, D.; Gibert, I.; MacKenzie, S. A.; Estepa, A.; Maspoch, D.; Roher, N. Targeting and stimulation of the zebrafish (Danio rerio) innate immune system with LPS/dsRNA-loaded nanoliposomes. Vaccine 2014, 32, 3955-3962.

34. Mackenzie, S.; Planas, J. V.; Goetz, F. W. LPS-stimulated expression of a tumor 
necrosis factor-alpha mRNA in primary trout monocytes and in vitro differentiated macrophages. Dev. Comp. Immunol. 2003, 27, 393-400.

35. Rombout, J. H. W. M.; Abelli, L.; Picchietti, S.; Scapigliati, G.; Kiron, V. Teleost intestinal immunology. Fish Shellfish Immunol. 2011, 31, 616-626.

36. Zhang, Y.-A.; Salinas, I.; Li, J.; Parra, D.; Bjork, S.; Xu, Z.; LaPatra, S. E.; Bartholomew, J.; Sunyer, J. O. IgT, a primitive immunoglobulin class specialized in mucosal immunity. Nature Immunology 2010, 11, 827-835.

37. Azizi, A.; Kumar, A.; Diaz-Mitoma, F.; Mestecky, J. Enhancing Oral Vaccine Potency by Targeting Intestinal M Cells. PLoS Pathog 2010, 6, e1001147.

38. Mullen, L.; Adams, G.; Layward, L.; Vessillier, S.; Annenkov, A.; Mittal, G.; Rigby, A.; Sclanders, M.; Baker, D.; Gould, D.; Chernajovsky, Y. Latent cytokines for targeted therapy of inflammatory disorders. Expert Opin. Drug Deliv. 2014, 11, 101-110.

39. Lathuilière, A.; Mach, N.; Schneider, B. Encapsulated Cellular Implants for Recombinant Protein Delivery and Therapeutic Modulation of the Immune System. IJMS 2015, 16, 10578-10600.

40. Villaverde, A.; Garcia-Fruitos E. ; Rinas, U.; Seras-Franzoso, J.; Kosoy, A.; Corchero, J. L.; Vazquez, E. Packaging protein drugs as bacterial inclusion bodies for therapeutic applications. Microb Cell Fact 2012, 11, 1-1.

41. Fredriksen, B. N.; Grip, J. PLGA/PLA micro- and nanoparticle formulations serve as antigen depots and induce elevated humoral responses after immunization of Atlantic salmon (Salmo salar L.). Vaccine 2012, 30, 656-667.

42. Menke, A. L.; Spitsbergen, J. M.; Wolterbeek, A. P. M.; Woutersen, R. A. Normal Anatomy and Histology of the Adult Zebrafish. Toxicologic Pathology 2011, 39, 759775.

43. Zapata, A.; Diez, B.; Cejalvo, T.; Gutiérrez-de Frías, C.; Cortés, A. Ontogeny of the immune system of fish. Fish Shellfish Immunol. 2006, 20, 126-136.

44. Hadidi, S.; Glenney, G. W.; Welch, T. J.; Silverstein, J. T.; Wiens, G. D. Spleen Size Predicts Resistance of Rainbow Trout to Flavobacterium psychrophilum Challenge. The Journal of Immunology 2008, 180, 4156-4165.

45. Wittamer, V.; Bertrand, J. Y.; Gutschow, P. W.; Traver, D. Characterization of the mononuclear phagocyte system in zebrafish. Blood 2011, 117, 7126-7135.

46. Mebius, R. E.; Kraal, G. Structure and function of the spleen. Nature reviews Immunology 2005, 5, 606-616.

47. Rombout, J.; Bot, H. E.; Tavernethiele, J. J. Immunological Importance of the 2nd Gut Segment of Carp .2. Characterization of Mucosal Leukocytes. Journal of Fish Biology 1989, 35, 167-178.

48. Sunyer, J. O. Fishing for mammalian paradigms in the teleost immune system. Nature Immunology 2013, 14, 320-326.

49. Parra, D.; Reyes-Lopez, F. E.; Tort, L. Mucosal Immunity and B Cells in Teleosts: Effect of Vaccination and Stress. Front Immunol 2015, 6, 354..

50. Rombout, J. H. W. M.; Yang, G.; Kiron, V. Fish \& Shell. Fish Shellfish Immunol 2014, 40, 634-643.

51. Joosten, P.; Tiemersma, E.; Threels, A.; CaumartinDhieux, C.; Rombout, J. Oral vaccination of fish against Vibrio anguillarum using alginate microparticles. Fish Shellfish Immunol 1997, 7, 471-485. 


\section{Figures}

A

IB $^{\text {TNFa }}$
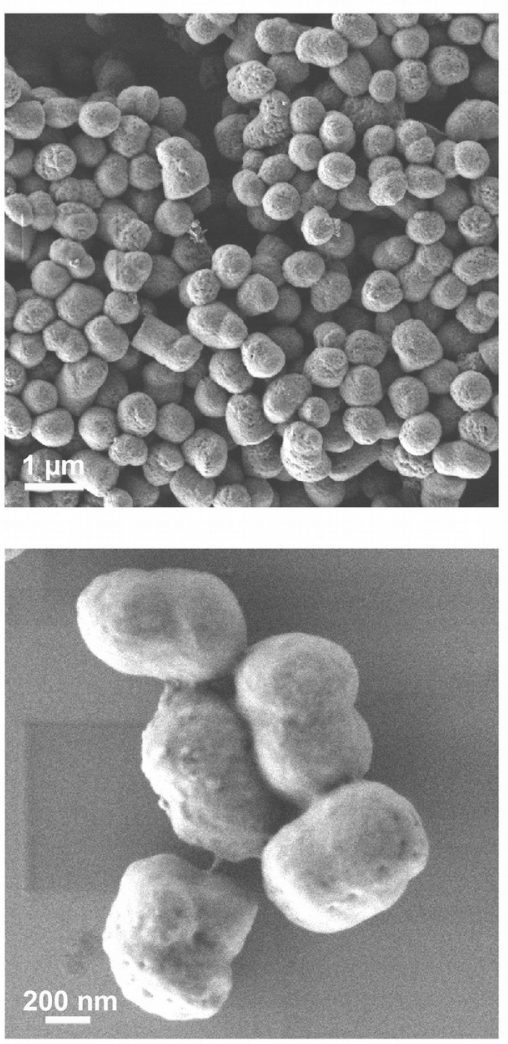

B
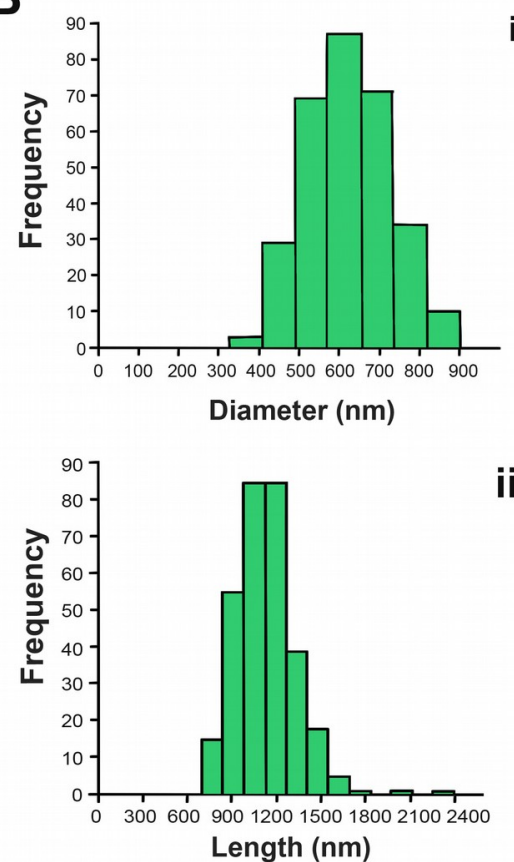

ii
$\mathrm{IB}^{\mathrm{CCL} 4}$
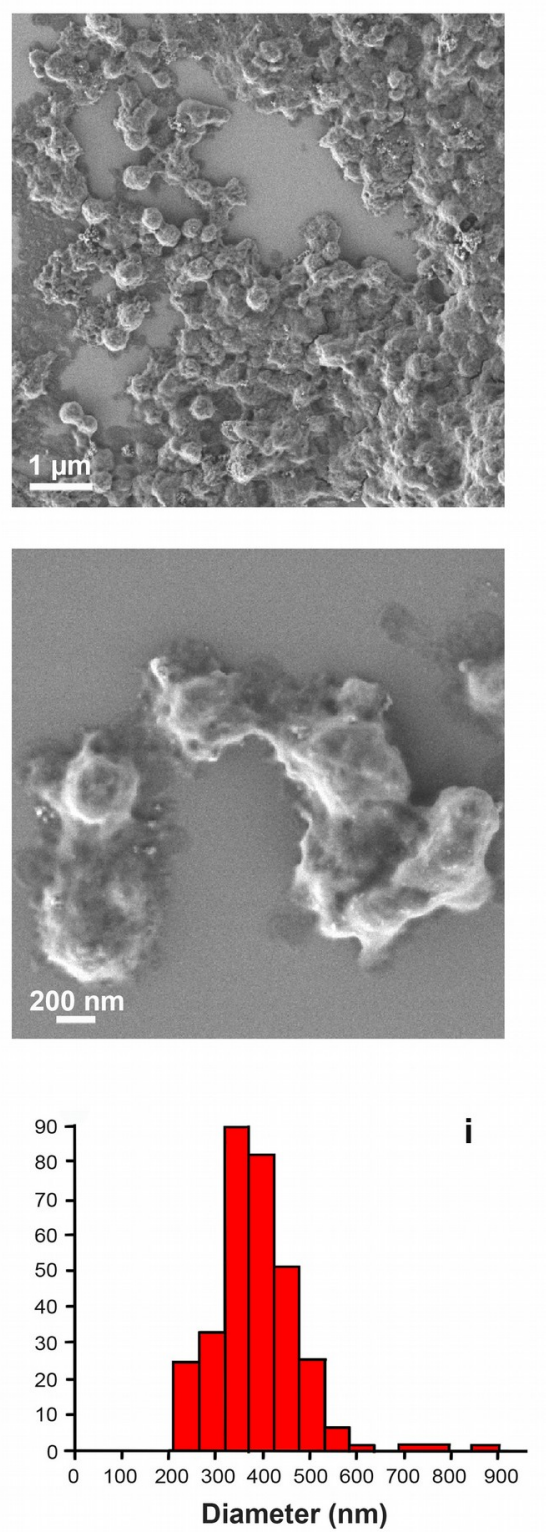
Figure 1. Characterization of the inclusion bodies (IBs) nanoparticles. (A) FESEM images of $\mathrm{IB}^{\mathrm{TNF} \alpha}$ and $\mathrm{IB}^{\mathrm{CCL} 4}$. (B) Size distribution of the $\mathrm{IB}^{\mathrm{TNF} \alpha}$ and IB ${ }^{\mathrm{CCL} 4}$, diameter (i) and length (ii).

A

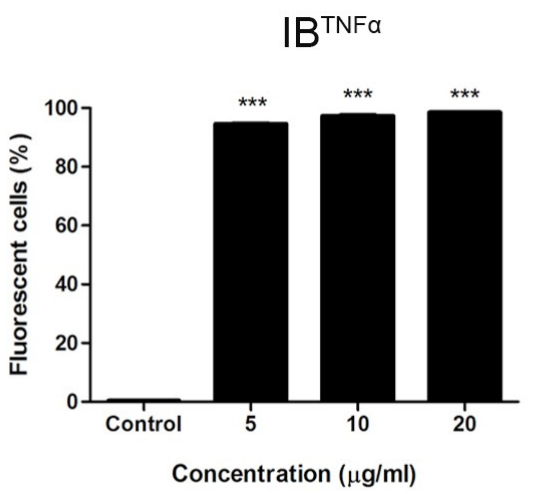

B
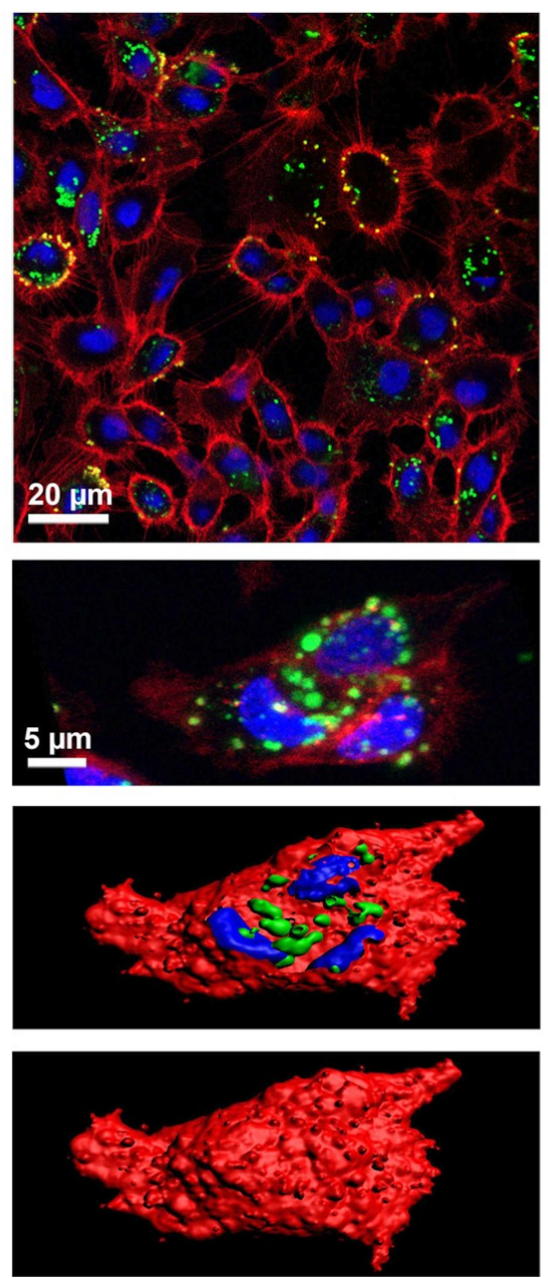
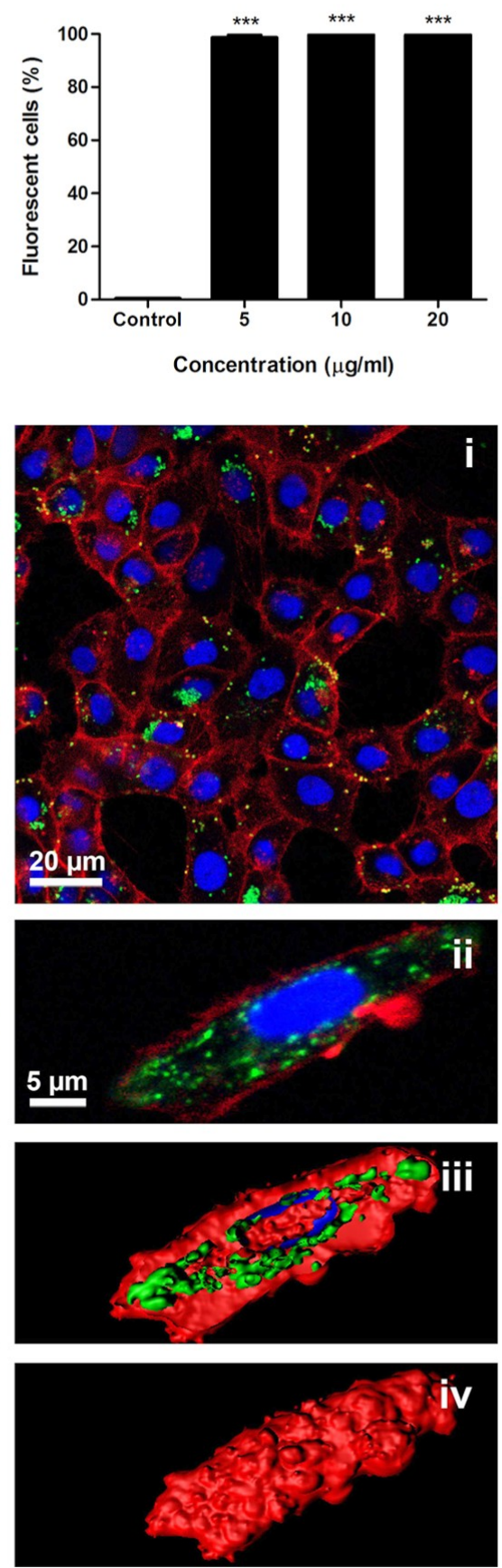

Figure 2. Uptake of IB $^{\text {TNF } \alpha}$ and IB $^{\text {CCL4 }}$ by ZFL cells. (A) Dose-response. Cells were incubated with 5 to $20 \mu \mathrm{g} / \mathrm{ml} \mathrm{IB}{ }^{\mathrm{TNF} \alpha}$ and $\mathrm{IB}^{\mathrm{CCL} 4}$ for $12 \mathrm{~h}$. Data represent mean $\pm \mathrm{SD}(n=$ 3). Differences were analyzed using one-way ANOVA and Tukey's post test. Significant differences against control: ***, $p<0.0001$. (B) Confocal microscopy images of $\mathrm{IB}^{\mathrm{TNF} \alpha}$ 
and IB $^{\text {CCL4 }}$ (green) uptake by ZFL cells (i). Cells were incubated $12 \mathrm{~h}$ with $10 \mu \mathrm{g} / \mathrm{ml}$ of $\mathrm{IB}^{\mathrm{TNF} \alpha}$ and $\mathrm{IB}^{\mathrm{CCL} 4}$. Cell membranes are shown in red and nuclei in blue (ii). Digitalized image of the same cells, z-stack (iii) and whole-membrane (iv).
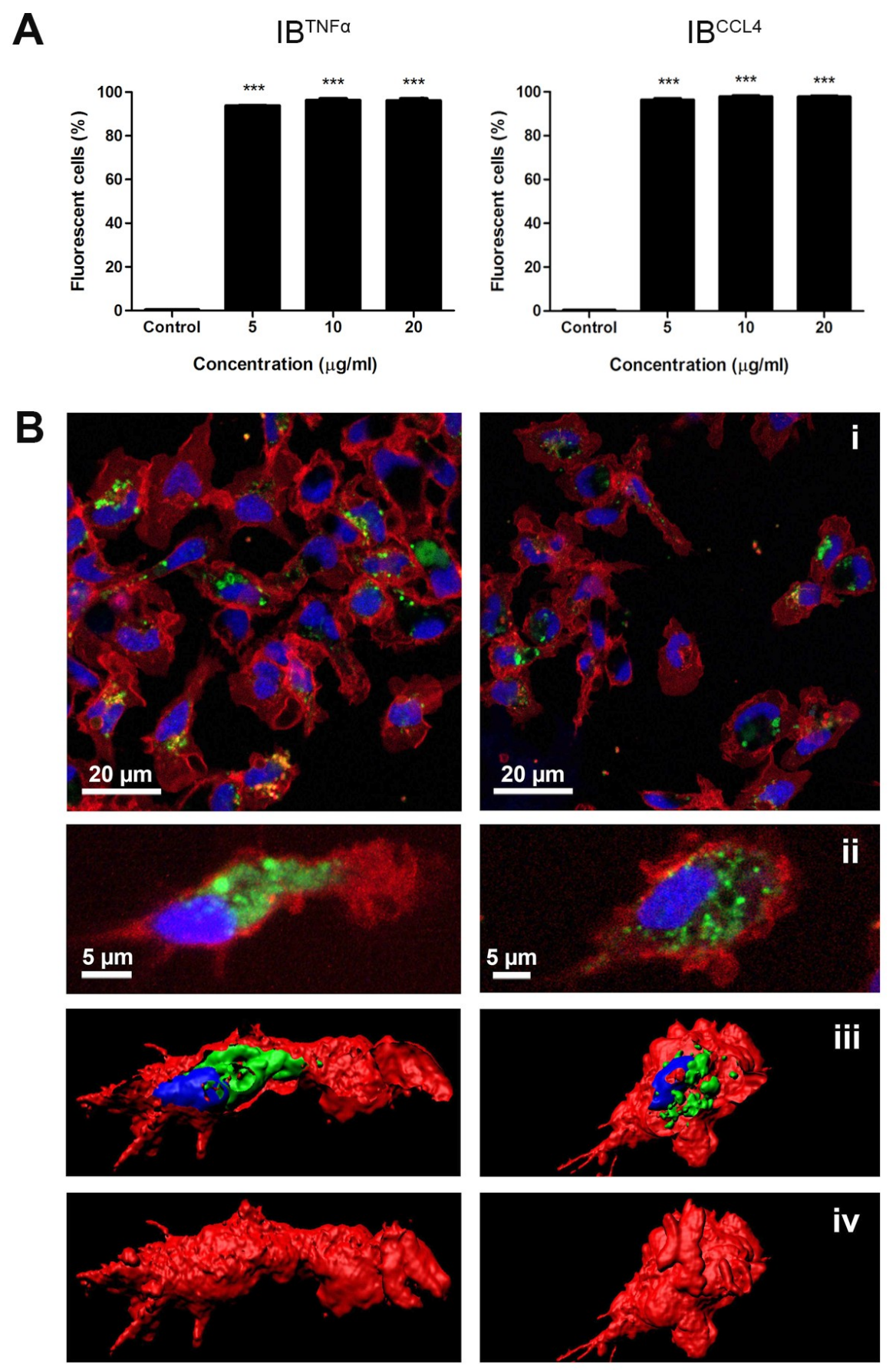

Figure 3. Uptake of IB $^{\text {TNFa }}$ and IB $^{\text {CCL4 }}$ by RT-HKM cells. (A) Cells were incubated with 5 to $20 \mu \mathrm{g} / \mathrm{ml} \mathrm{IB}{ }^{\mathrm{TNF} \alpha}$ and $\mathrm{IB}^{\mathrm{CCL} 4}$ for $12 \mathrm{~h}$. Data represent mean $\pm \mathrm{SD}(n=3)$. Differences were analyzed using one-way ANOVA and Tukey's post test. Significant 
differences against control: $* * *, p<0.0001$. (B) Confocal microscopy images of IB ${ }^{\mathrm{TNF} \alpha}$ and IB $^{\text {CCL4 }}$ (green) uptake by RT-HKM cells (i). Cells were incubated $12 \mathrm{~h}$ with 10 $\mu \mathrm{g} / \mathrm{ml}$ of $\mathrm{IB}^{\mathrm{TNF} \alpha}$ and IB ${ }^{\mathrm{CCL} 4}$. Cell membranes are shown in red and nuclei in blue (ii). Digitalized image of the same cells, z-stack (iii) and whole-membrane (iv).
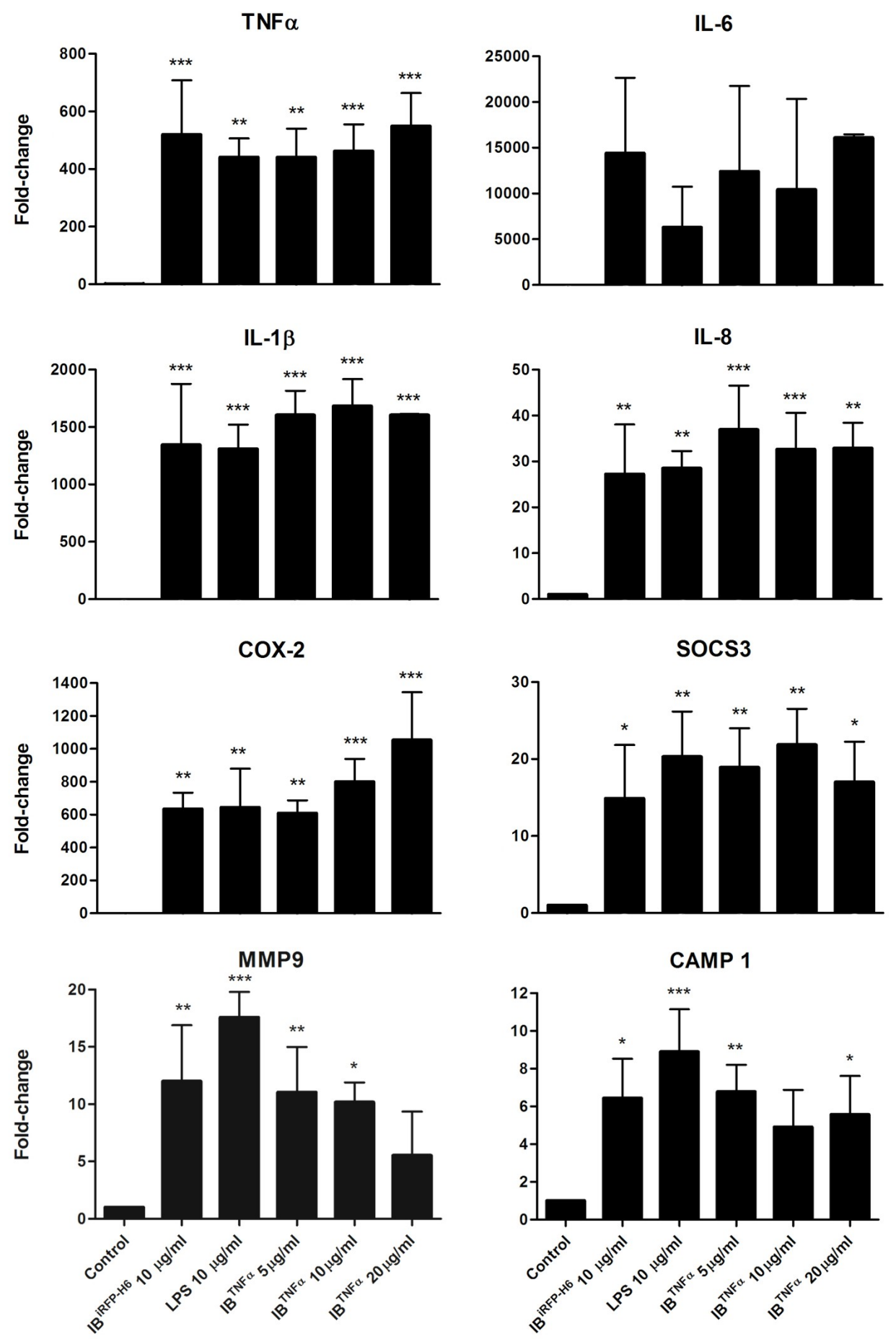

Figure 4. Gene expression analysis in RT-HKM cells stimulated with IB $^{\mathrm{TNF} \alpha}$, LPS and IB ${ }^{\text {iRFP-H6 }}$. Cells were incubated with $10 \mu \mathrm{g} / \mathrm{ml}$ of IB ${ }^{\mathrm{iRFP}-\mathrm{H} 6}, 10 \mu \mathrm{g} / \mathrm{ml} \mathrm{LPS}$ and 5, 10 
and $20 \mu \mathrm{g} / \mathrm{ml}$ of $\mathrm{IB}^{\mathrm{TNF} \alpha}$ for $12 \mathrm{~h}$. The gene expression was analyzed by Q-PCR. Data represent mean \pm SD $(n=3)$. Differences were analyzed using one-way ANOVA and Tukey’s post test. Significant differences respect control (*, $p<0.05 ; * *, p<0.01$; ***, $p<0.001)$ and LPS (a, $p<0.05)$.

A

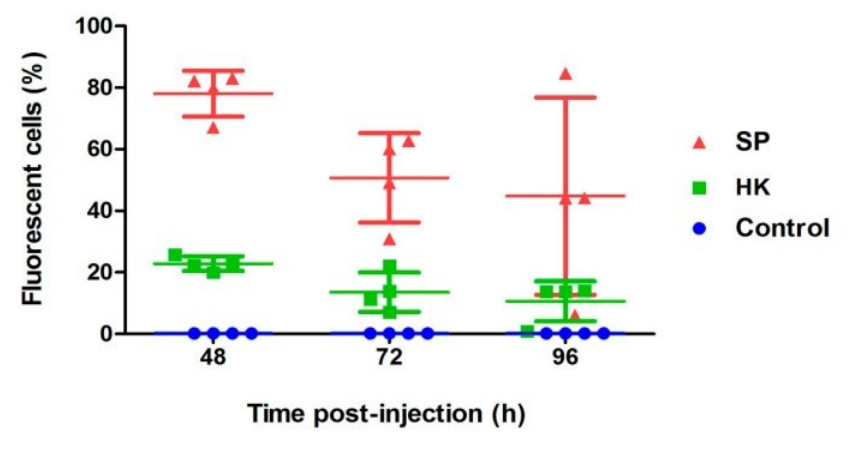

B
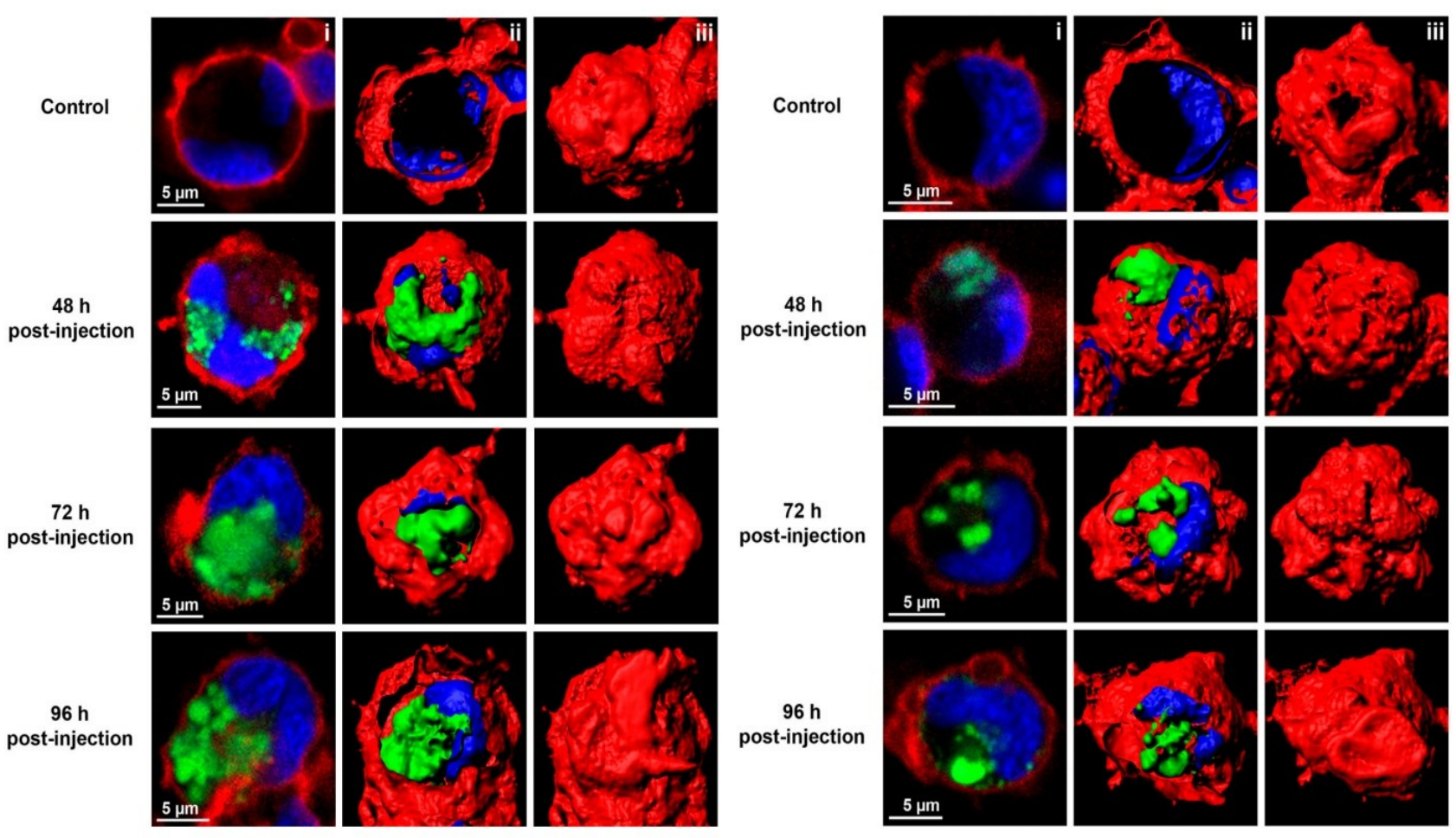

Figure 5. In vivo uptake of $\mathrm{IB}^{\mathrm{TNF} \alpha}$ by phagocyte cells from spleen and head kidney.

(A) Quantification of IB $^{\mathrm{TNF} \alpha}$ uptake by phagocytes from spleen, SP (red triangles) and 
head kidney, HK (green squares) after 48, 72 and 96 h post-injection. Data represent mean \pm SD $(n=4)$. Confocal images of phagocytes from spleen $(\mathbf{B})$ and head kidney (C) at 48, 72 and $96 \mathrm{~h}$ post-injection (i). 3D image analysis of IB ${ }^{\mathrm{TNF} \alpha}$ uptake (z-stack) (ii) and whole-membrane reconstruction (iii).

A

\begin{tabular}{lcc}
\hline \multicolumn{1}{c}{ IBs } & Dose $(\boldsymbol{\mu g})$ & RPS (\%) \\
\hline IB $^{\text {TNF } \alpha}$ & 300 & 100 \\
IB $^{\text {CCL4 }}$ & 75 & 91 \\
IB $^{\text {iRFP-H6 }}$ & 300 & 37 \\
\hline
\end{tabular}

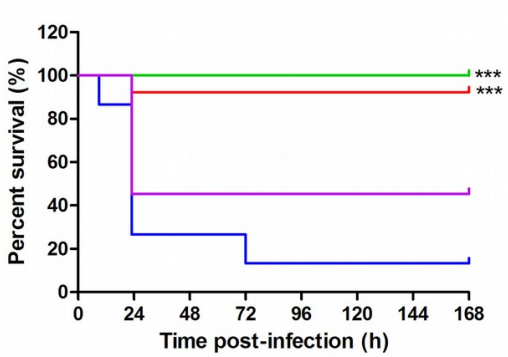

B

\begin{tabular}{lcc}
\hline \multicolumn{1}{c}{ IBs } & Dose ( $\mu \mathrm{g})$ & RPS (\%) \\
\hline IB $^{\text {TNF } \alpha}$ & 150 & 65 \\
IB $^{\text {CCL4 }}$ & 75 & 91 \\
IB $^{\text {iRFP-H6 }}$ & 150 & 48 \\
\hline
\end{tabular}

ii

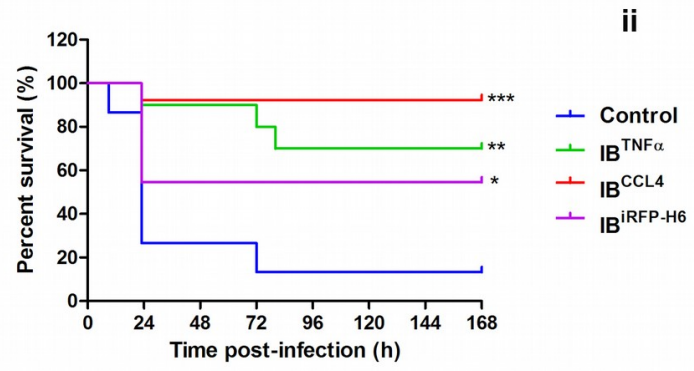

Figure 6. Survival of the zebrafish after i.p. injection with $\mathrm{IB}^{\mathrm{TNF} \alpha}, \mathrm{IB}^{\mathrm{CCL} 4}$ and $\mathrm{IB}^{\mathrm{iRFP}-}$ ${ }^{\mathrm{H} 6}$ and challenge with $P$. aeruginosa. (A) The $\mathrm{IB}^{\mathrm{TNF} \alpha}$ and $\mathrm{IB}^{\mathrm{iRFP}-\mathrm{H} 6}$ dose was $300 \mu \mathrm{g}$ and the $\mathrm{IB}^{\mathrm{CCL} 4}$ dose $75 \mu \mathrm{g}$, and $(\mathbf{B})$ the $\mathrm{IB}^{\mathrm{TNF} \alpha}$ and $\mathrm{IB}^{\mathrm{iRFP}-\mathrm{H} 6}$ dose was $150 \mu \mathrm{g}$ and the $\mathrm{IB}^{\mathrm{CCL} 4}$ dose $75 \mu$ g. (i) Table showing the relative percentage of survival (RPS). (ii) Zebrafish survival curves after i.p. injection with $\mathrm{IB}^{\mathrm{TNF} \alpha}$, $\mathrm{IB}^{\mathrm{CCL} 4}$ or $\mathrm{IB}^{\mathrm{iRFP}-\mathrm{H} 6}$ and challenged with $P$. aeruginosa PAO1 $\left(\mathrm{LD}_{50}\right)\left(4 \times 10^{7} \mathrm{cfu} /\right.$ dose $)(\mathrm{n}=15)$. Untreated zebrafish that had been infected with PAO1 were used as mortality control. Significant differences were analyzed using the log-rank test; **, $p<0.01$; $^{* *}, p<0.0001$. 

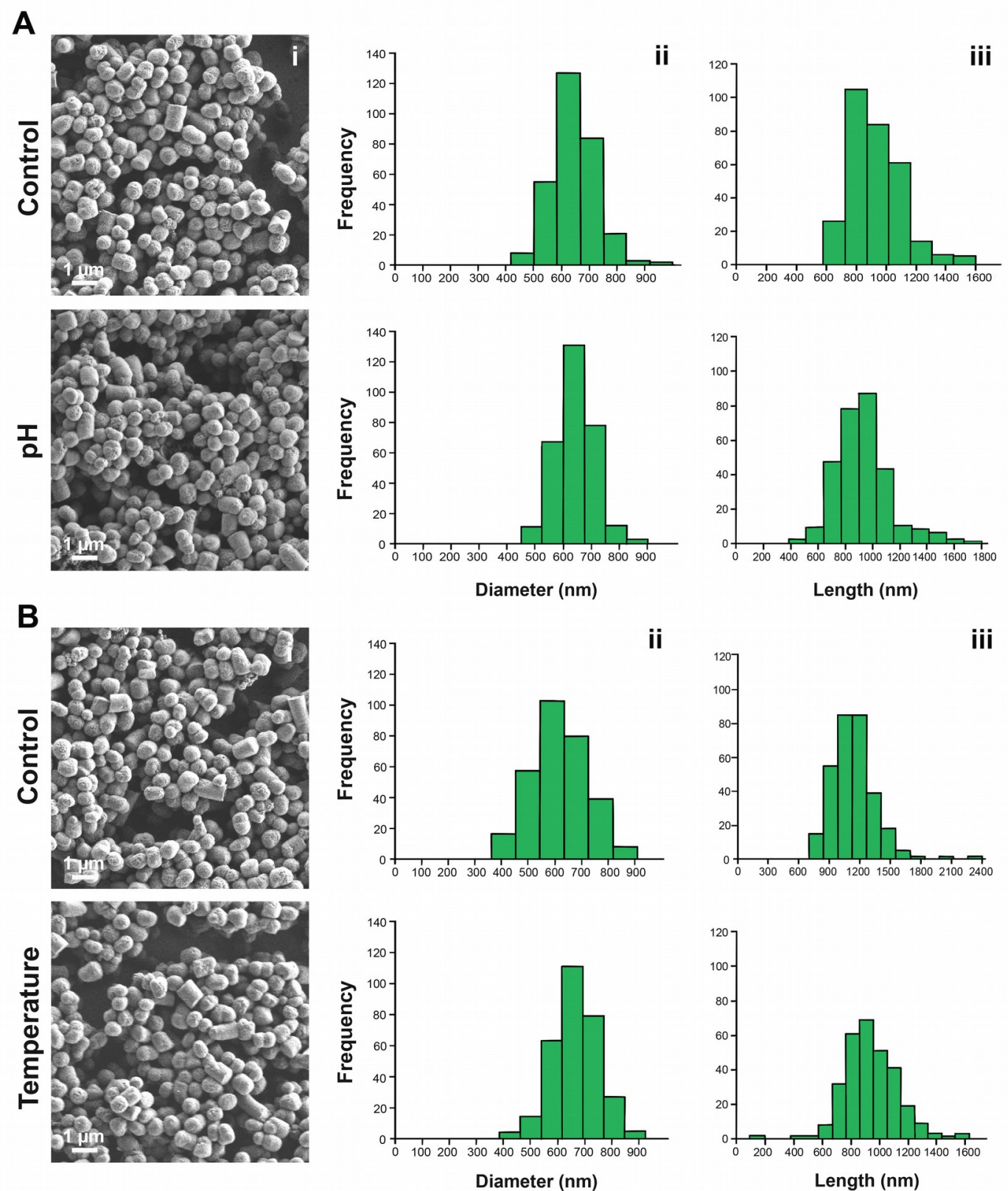

C

D
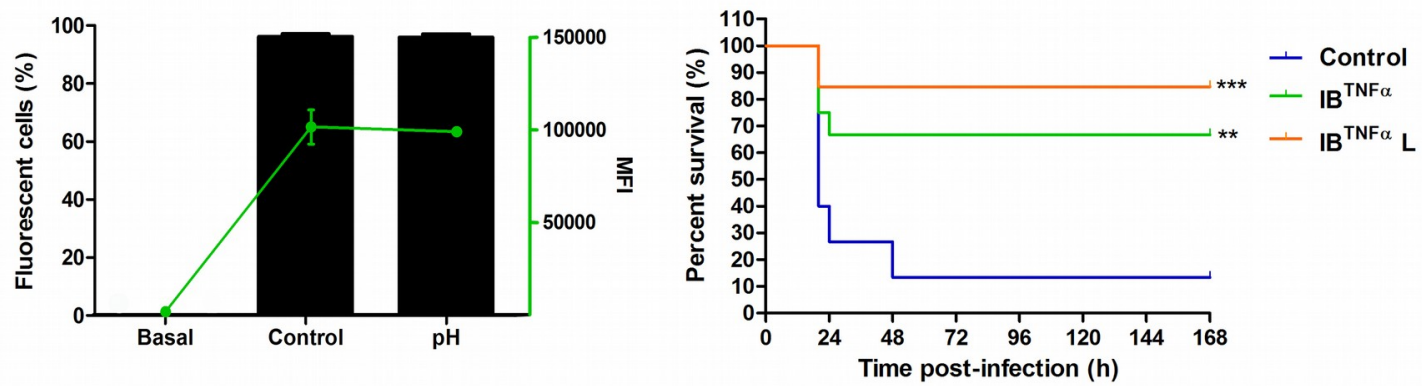
Figure 7. Characterization of $\mathrm{IB}^{\mathrm{TNF} \alpha}$ particle stability under extreme $\mathbf{p H}$, temperature and lyophilization conditions. (A) FESEM images and (B) size distribution, diameter (i) and length (ii)) of $\mathrm{IB}^{\mathrm{TNF} \alpha}$ at different $\mathrm{pH}(\mathrm{pH} 2.5$ for $3 \mathrm{~h}$ and then $\mathrm{pH} 8$ for 6 h) and high temperature (C) Percentage of fluorescent cells and Mean Fluorescent Intensity (MFI) of RT-HKM after stimulation with TNFo-Atto488 IBs previously incubated at $\mathrm{pH} 2.5$ for $3 \mathrm{~h}$ and then $\mathrm{pH} 8$ for $6 \mathrm{~h}$. (D) Immunization of zebrafish with lyophilized $\mathrm{IB}^{\mathrm{TNF} \alpha}(\mathrm{L})$. Survival curves after i.p. injection of control and lyophilized $\mathrm{IB}^{\mathrm{TNF} \alpha}$ after the challenge with P. aeruginosa PAO1 $\left(\mathrm{LD}_{50}\right)\left(3.4 \times 10^{7}\right.$ $\mathrm{cfu} / \mathrm{dose})(\mathrm{n}=15)$. Untreated zebrafish that had been infected with PAO1 were used as mortality control. The control and lyophilized $\mathrm{IB}^{\mathrm{TNF} \alpha}$ dose was $300 \mu \mathrm{g}$. Significant differences were analyzed using the log-rank test; **, $p<0.01$; ***, $p<0.0001$. 
A

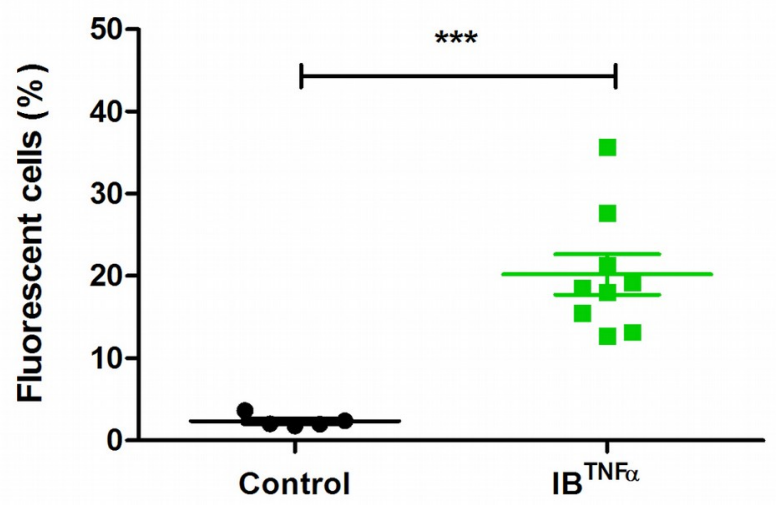

B

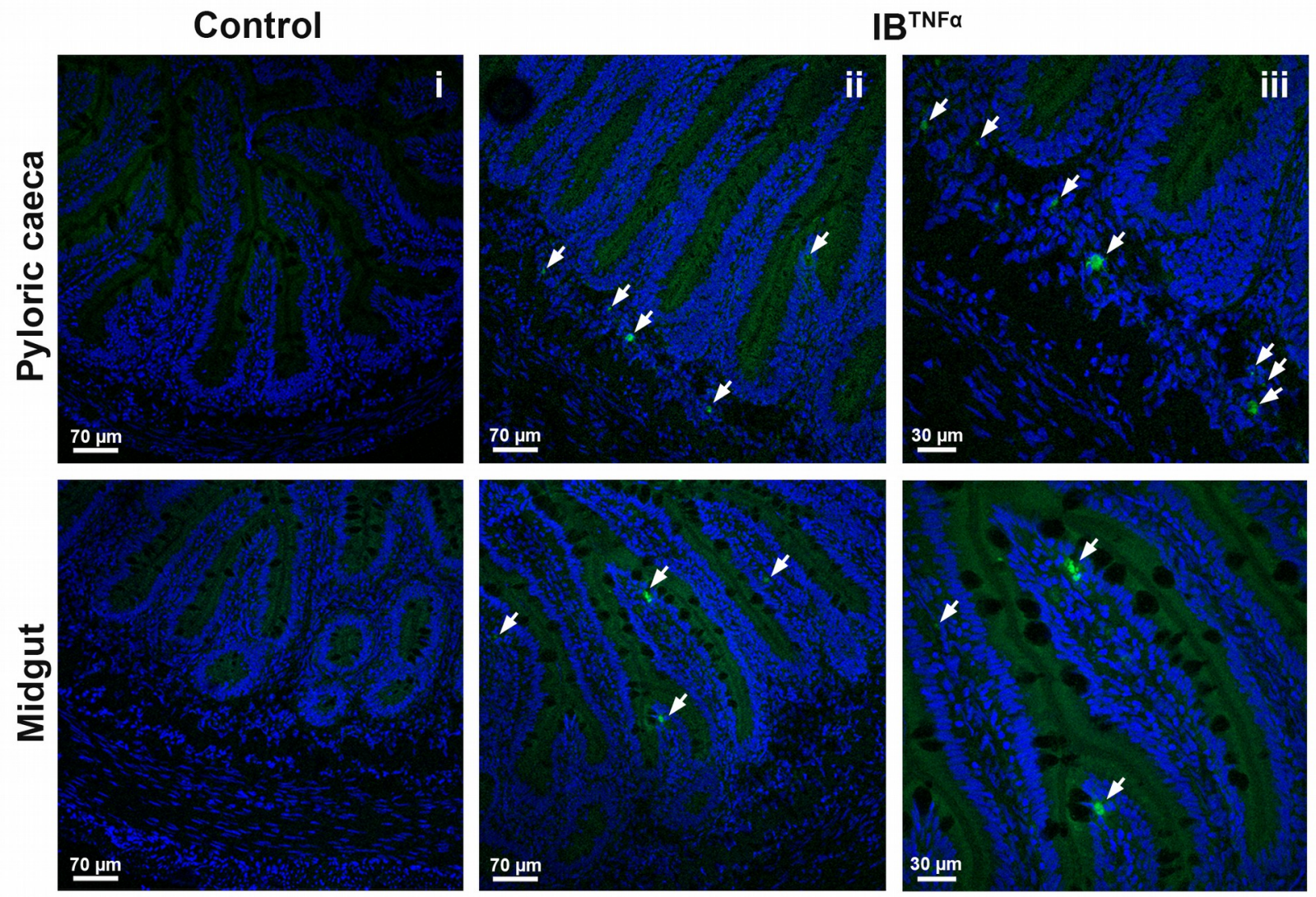

Figure 8. In vivo uptake of $\mathrm{IB}^{\mathrm{TNF} \alpha}$ by cells of the intestinal mucosa. (A) Percentage of fluorescent cells in animals intubated with $1 \mu \mathrm{g} /$ fish of IB $^{\text {TNFa }}$-Atto488 IBs after $24 \mathrm{~h}$. Data represent mean \pm SD (Control, $n=5$ individuals, IB $^{\mathrm{TNF} \alpha}, n=9$ individuals). Differences were analyzed using t-test. Significant differences respect to control ***, $p<0.001$. (B) Confocal images of intestine cells from pyloric caeca and midgut $24 \mathrm{~h}$ post-intubation. Control (i), IB ${ }^{\mathrm{TNF} \alpha}$ (ii), and $\mathrm{IB}^{\mathrm{TNF} \alpha}$ at higher magnification (iii). White arrows indicate the $\mathrm{IB}^{\mathrm{TNF} \alpha}$-Atto488 IBs. 


\section{Supplementary Tables and Figures}

Table S1. Rainbow trout primers for Q-PCR and CCL4 cloning.

\begin{tabular}{|c|c|c|c|}
\hline Gene & Primer name & Sequence & Accession $n^{\circ}$ \\
\hline Plasmid Chemokine (C-C motif) ligand 4 & om_pCCL4 & $\begin{array}{l}\text { For_GGTATTGAGGGTCGCTTCACCCCTCGTCTTGCTATGCT } \\
\text { Rev_AGAGGAGAGTTAGAGCCTTACAGGAGTGGTGTCTGCTCCCCA }\end{array}$ & AY561709.1 \\
\hline Elongation factor $1 \alpha$ & om_EF-1 & $\begin{array}{l}\text { For_CAAGGATATCCGTCGTGGCA } \\
\text { Rev_ACAGCGAAACGACCAAGAGG }\end{array}$ & NM_001124339.1 \\
\hline Tumor necrosis factor $\alpha$ & om_TNFa & $\begin{array}{l}\text { For_CGCTGACACAGTGCAGTGGA } \\
\text { Rev_TCCCCGATGGAGTCCGAATA }\end{array}$ & NM_001124357.1 \\
\hline Interleukin 6 & om_IL-6 & $\begin{array}{l}\text { For_TTTCAGAAGCCCGTGGAAGAGA } \\
\text { Rev_TCTTTGACCAGCCCTAATCAGCA }\end{array}$ & NM_001124657.1 \\
\hline Interleukin $1 \beta$ & om_IL-1 $\beta$ & $\begin{array}{l}\text { For_GGAGGCAGCAGCTACCACAAA } \\
\text { Rev_CCGATTTGGAGCAGGACAGG }\end{array}$ & NM_001124347.2 \\
\hline Interleukin 8 & om_IL-8 & $\begin{array}{l}\text { For_AGAATGTCAGCCAGCCTTGT } \\
\text { Rev_TCTCAGACTCATCCССTCAGT }\end{array}$ & AJ279069 \\
\hline Cyclooxygenase 2 & om_COX-2 & $\begin{array}{l}\text { For_TACCAAGCAGATCGCTGGAC } \\
\text { Rev_GCGTATGGCTTCATGGAGAA }\end{array}$ & NM_001124348.1 \\
\hline Suppressor of cytokine signaling 3 & om_SOCS3 & $\begin{array}{l}\text { For_AACAACACAAGATATCAAGCTCAAG } \\
\text { Rev_GAAGGTCTTGTAACGGTGAGGCAG }\end{array}$ & AM748723.1 \\
\hline Matrix metalloproteinase 9 & om_MMPg & $\begin{array}{l}\text { For_TTCCAATTCAAGGGCAACTC } \\
\text { Rev_TCAGCCCCCACAGTTAAGAG }\end{array}$ & NM_001124370.1 \\
\hline Cathelicidin 1 & om_CAMP1 & $\begin{array}{l}\text { For_GGCTGACCTTCCCCATACAG } \\
\text { Rev_CAGGTTGTTGCTTGCCTCC }\end{array}$ & NM_001124480.1 \\
\hline
\end{tabular}


A

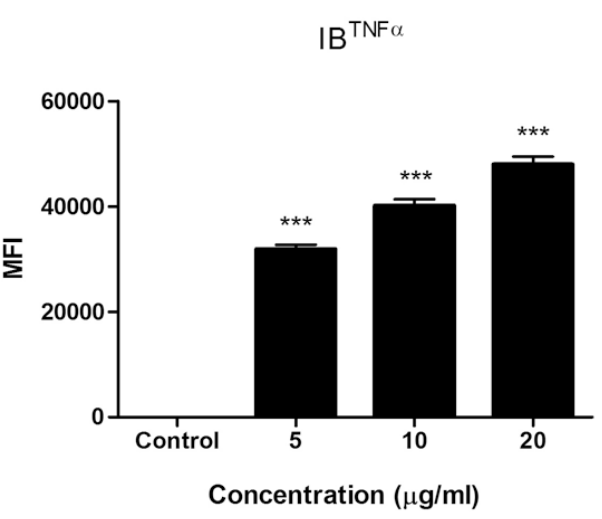

B

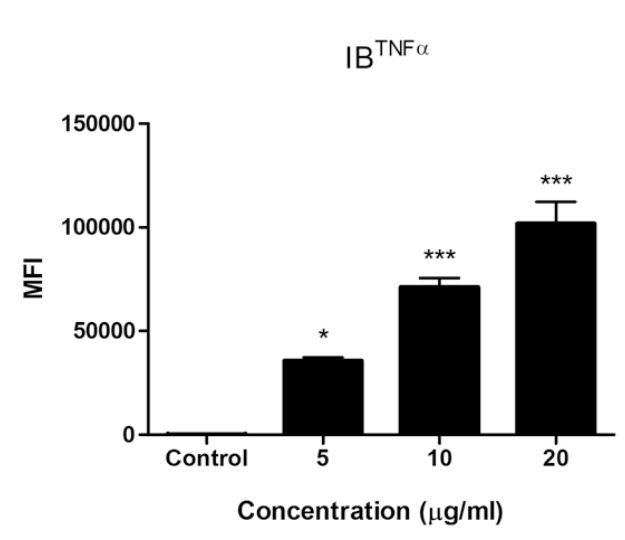

$\mathrm{IB}^{\mathrm{CCL} 4}$
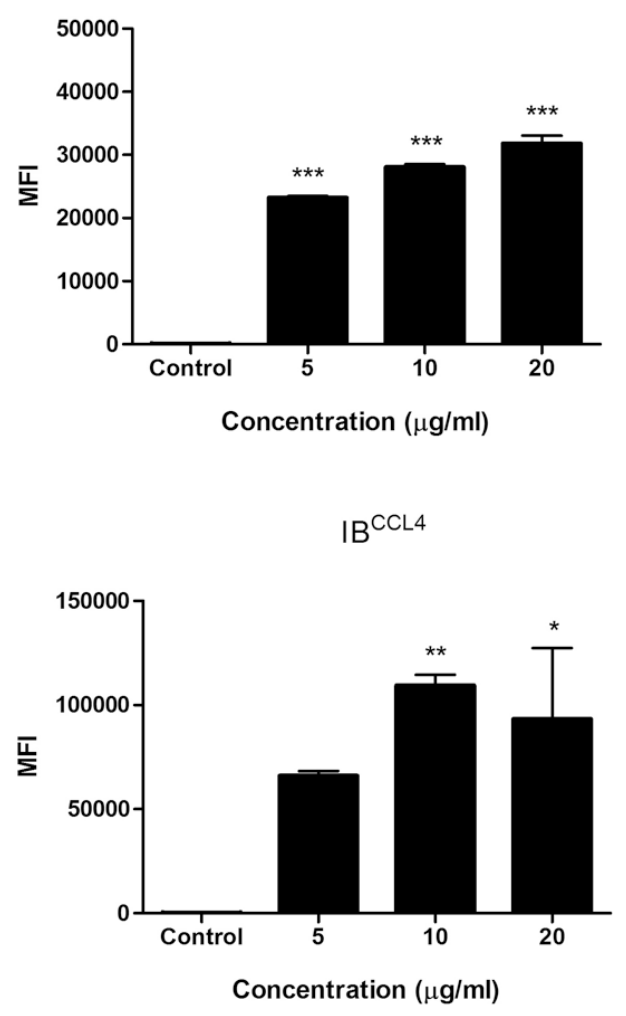

Figure S1. Mean fluorescent intensity (MFI) in the uptake of the IBs. Dose-response in A) ZFL and B) RT-HKM. Cells were incubated with 5 to $20 \mu \mathrm{g} / \mathrm{ml}$ of IB $^{\text {TNFa }}$ or IB ${ }^{\text {CCL4 }}$ for $12 \mathrm{~h}$. The gene expression was analyzed by Q-PCR. Data represent mean \pm SD $(n=$ 3). Differences were analyzed using one-way ANOVA and Tukey's post-test. Significant differences respect to control: a, $p<0.001$; b, $p<0.01$ and c, $p<0.05$, and between doses: *, $p<0.05$; **, $p<0.01 ; * * *, p<0.001$. 
TNF $\alpha$

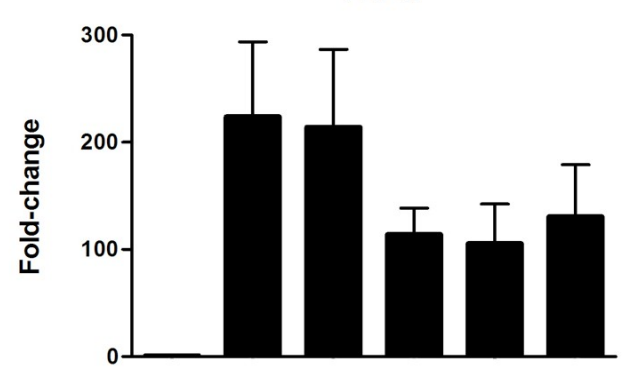

IL-1 $\beta$

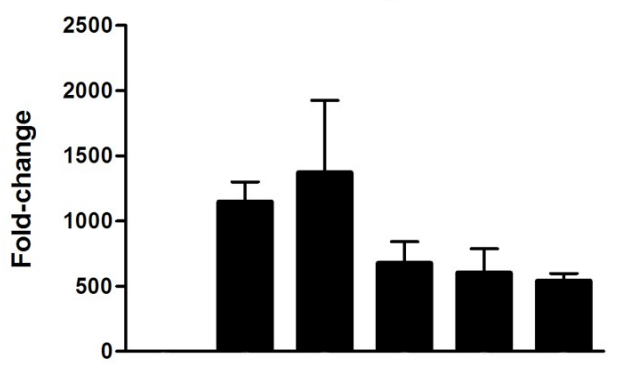

cox-2

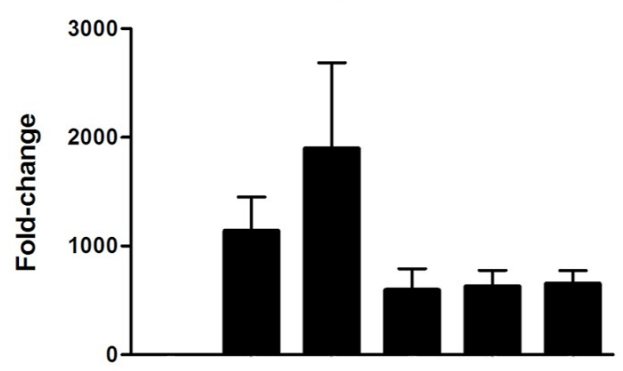

MMP9

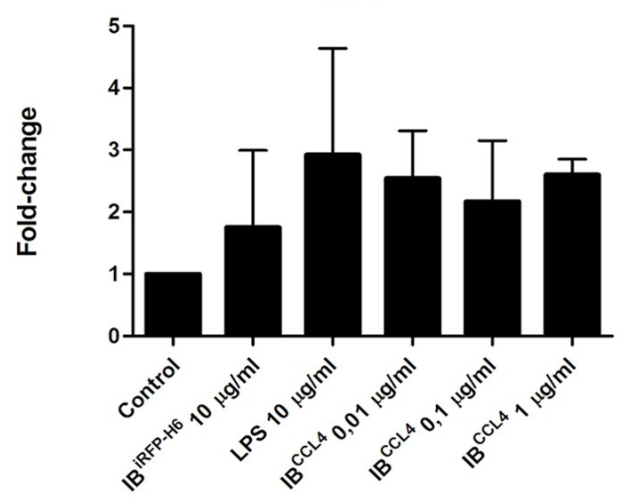

IL-6

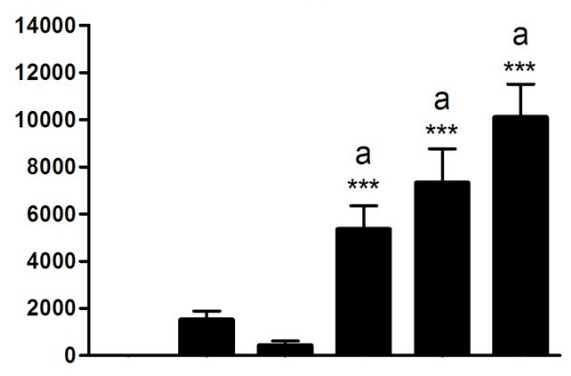

IL-8

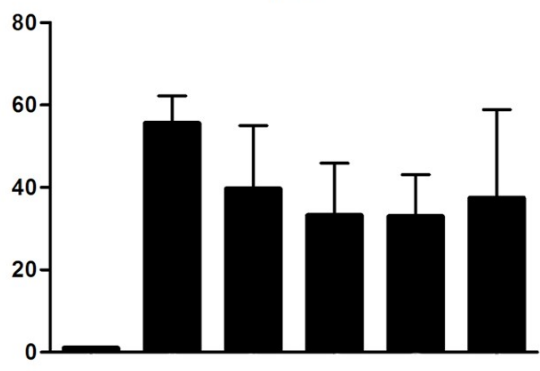

socs3

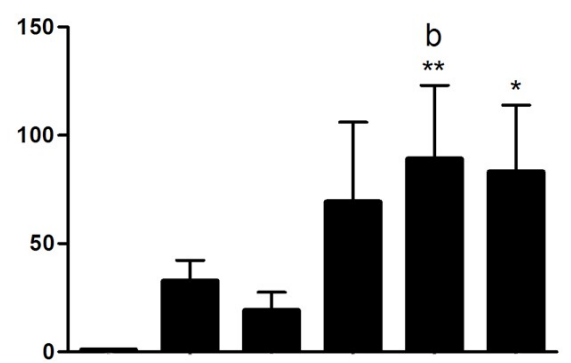

CAMP1

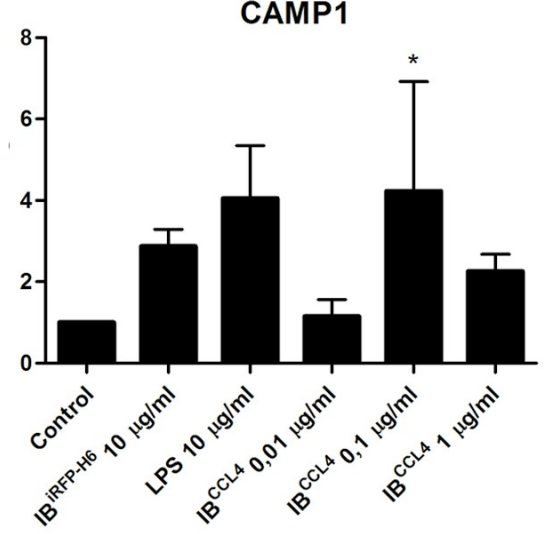

Figure S2. Analysis of the gene expression in RT-HKM cells stimulated with IB $^{\text {iRFP- }}$ ${ }^{\text {H6 }}$, LPS and IB ${ }^{\text {CCL4}}$. Cells were incubated with $10 \mu \mathrm{g} / \mathrm{ml}$ of IB ${ }^{\text {iRFP-H6 }}, 10 \mu \mathrm{g} / \mathrm{ml} \mathrm{LPS}$ and 0.01, 0.1 and $1 \mu \mathrm{g} / \mathrm{ml}$ of IB ${ }^{\mathrm{CCL} 4}$ for $12 \mathrm{~h}$. The gene expression was analyzed by Q-PCR. Data represent mean \pm SD $(n=3)$. Differences were analyzed using one-way ANOVA and Tukey's post-test. Significant differences respect to $\operatorname{IB}^{\mathrm{iRFP}-\mathrm{H} 6}$ (a, $p<0.001$; $\mathrm{b}, p<0.05$ ) and LPS (*, $p<0.05 ; * *, p<0.01 ; * * *, p<0.001)$. 
Figure S3. Survival of the zebrafish after i.p. injection with $I^{\mathrm{TNF} \alpha}$ and challenge with $P$. aeruginosa. Zebrafish survival curves after i.p. injection with $\operatorname{IB}^{\mathrm{TNF} \alpha}$ and challenged with $P$. aeruginosa PAO1 $\left(\mathrm{LD}_{50}\right)\left(2.4 \times 10^{7} \mathrm{cfu} / \mathrm{dose}\right)(\mathrm{n}=19)$ at 30 days post-injection. The $\mathrm{IB}^{\mathrm{TNF} \alpha}$ dose was $300 \mu \mathrm{g}$. Untreated zebrafish that had been infected with PAO1 were used as mortality control. Significant differences were analyzed using the log-rank test; ${ }^{*}, p<0.05$. 
TNF $\alpha$

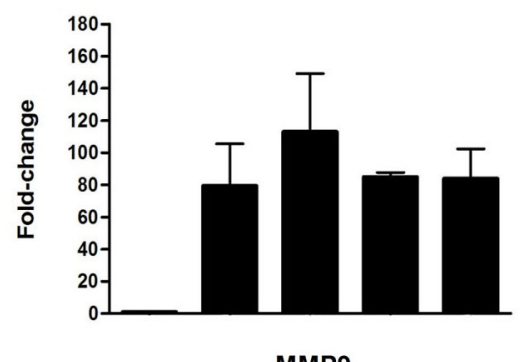

MMP9

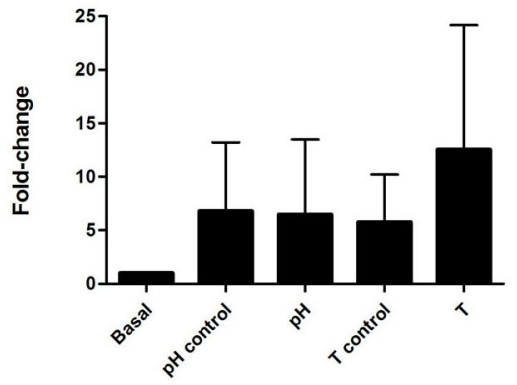

IL-1 $\beta$
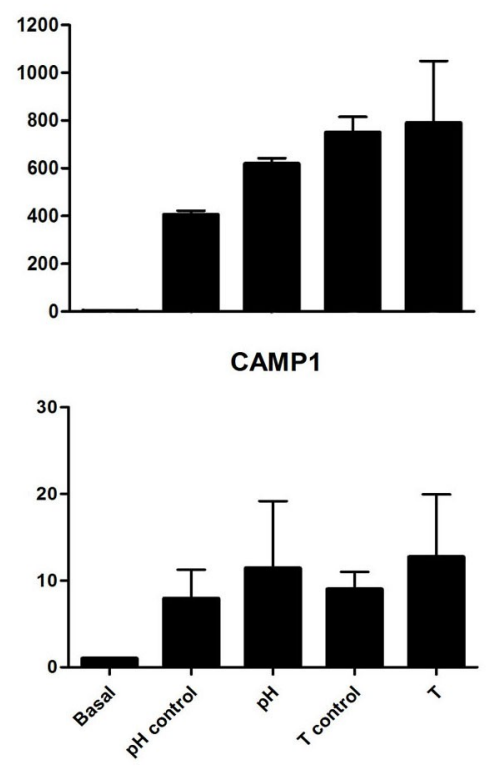

Figure S4. Analysis of TNF $\alpha$ and IL1 $\beta$ gene expression by Q-PCR in RT-HKM cells stimulated with $\mathrm{IB}^{\mathrm{TNF} \alpha}$ incubate at different $\mathrm{pH}$ and temperature conditions. Cells were incubated with $10 \mu \mathrm{g} / \mathrm{ml}$ of $\mathrm{IB}^{\mathrm{TNF} \alpha} \mathrm{pH}$ control, $\mathrm{IB}^{\mathrm{TNF} \alpha} \mathrm{pH}$, IB ${ }^{\mathrm{TNF} \alpha}$ temperature control (T control) and IB ${ }^{\mathrm{TNF} \alpha}$ temperature $(\mathrm{T})$. Data represent mean $\pm \mathrm{SD}(n=4)$. 
A
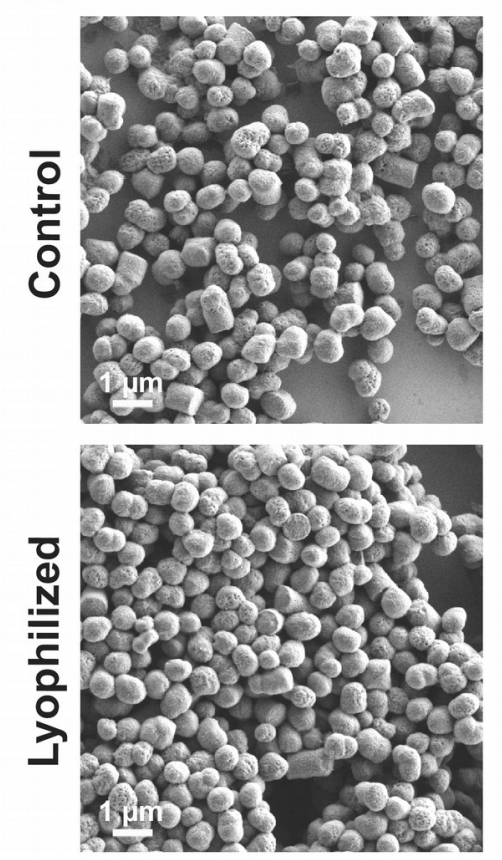

B
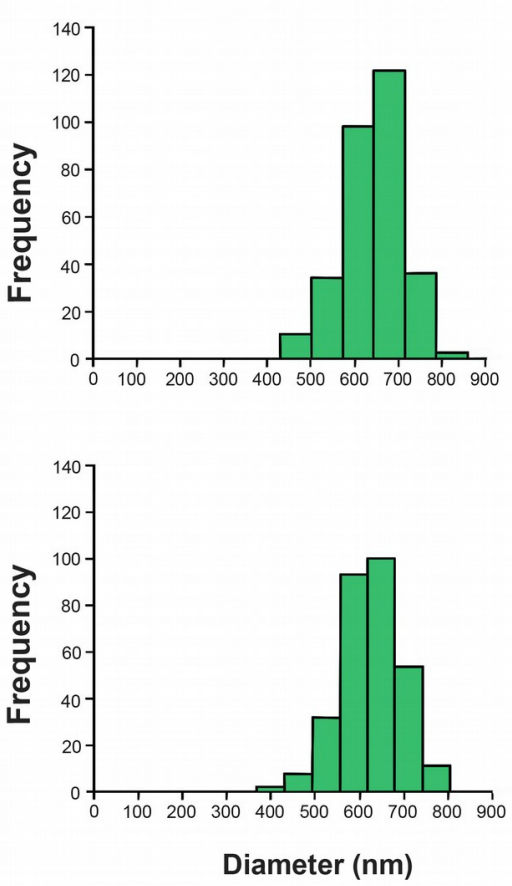
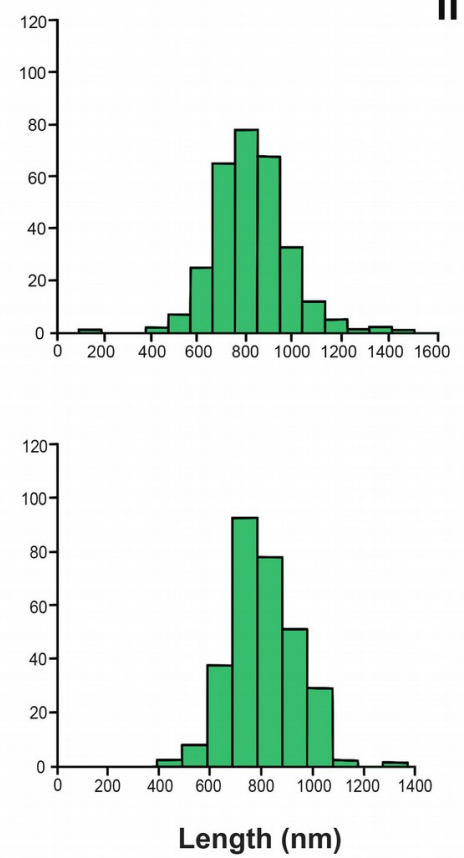

Figure S5. Characterization of lyophilized $\mathbf{I B}^{\mathrm{TNF} \alpha}$. (A) FESEM images and (B) size distribution of the control and lyophilized $\mathrm{IB}^{\mathrm{TNF} \alpha}$, diameter (i) and length (ii). 